\title{
GEOTHERMAL DIRECT APPLICATIONS HARDWARE SYSTEMS DEVELOPMENT AND TESTING - 1979 SUMMARY REPORT
}

Joseph G. Keller

Published March 1980

EG\&G Idaho, Inc. Idaho Falls, Idaho $\mathbf{8 3 4 1 5}$

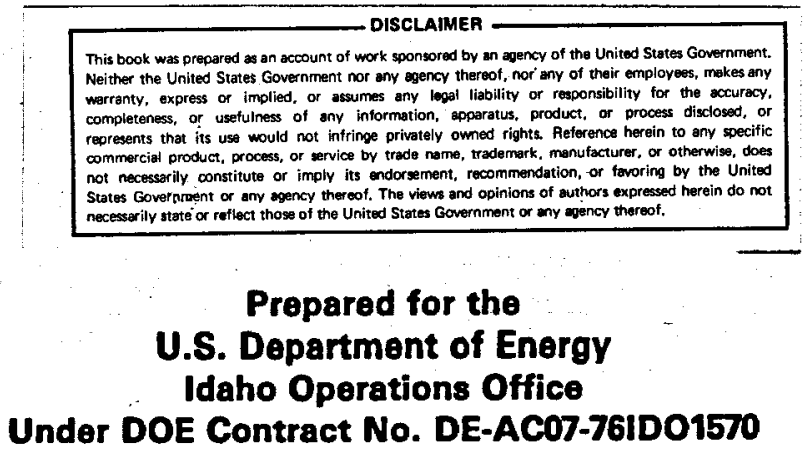




\section{DISCLAIMER}

This report was prepared as an account of work sponsored by an agency of the United States Government. Neither the United States Government nor any agency Thereof, nor any of their employees, makes any warranty, express or implied, or assumes any legal liability or responsibility for the accuracy, completeness, or usefulness of any information, apparatus, product, or process disclosed, or represents that its use would not infringe privately owned rights. Reference herein to any specific commercial product, process, or service by trade name, trademark, manufacturer, or otherwise does not necessarily constitute or imply its endorsement, recommendation, or favoring by the United States Government or any agency thereof. The views and opinions of authors expressed herein do not necessarily state or reflect those of the United States Government or any agency thereof. 


\section{DISCLAIMER}

Portions of this document may be illegible in electronic image products. Images are produced from the best available original document. 


\section{ABSTRACT}

The Department of Energy's Raft River Idaho Geothermal Test Site helps support the national hydrothermal direct applications activities. Portions of these activities are research tasks aimed at investigating new/alternative hardware systems or the modification of existing hardware technology to best utilize a geothermal resource.

Provided herein are activities performed during calendar year 1979 for the hardware system development and testing task. The fluidized bed technology was applied to the drying of potato by-products and to the exchange of heat to air in the space heating experiment. Geothermal water was flashed to steam and also used as the prime energy source in the steam distillation of peppermint bil. Geothermal water temperatures as low as $112.8^{\circ} \mathrm{C}$ were utilized to distill alcohol from sugar beet juice, and lower temperature water provided air conditioning through an absorption air conditioning system. These experiments are discussed in further detail in this report. 


\section{CONTENTS}

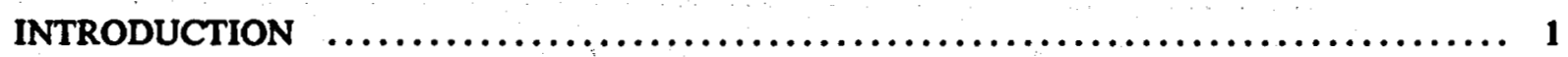

FLUIDIZED BED HEATER EXPERIMENT $\ldots \ldots \ldots \ldots \ldots \ldots \ldots \ldots \ldots \ldots \ldots \ldots \ldots \ldots$

Fluidized Bed Technology $\ldots \ldots \ldots \ldots \ldots \ldots \ldots \ldots \ldots \ldots \ldots \ldots \ldots \ldots \ldots \ldots \ldots \ldots, 1$

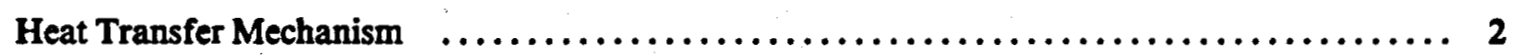

Potential Advantages $\ldots \ldots \ldots \ldots \ldots \ldots \ldots \ldots \ldots \ldots \ldots \ldots \ldots \ldots \ldots \ldots \ldots \ldots, 2$

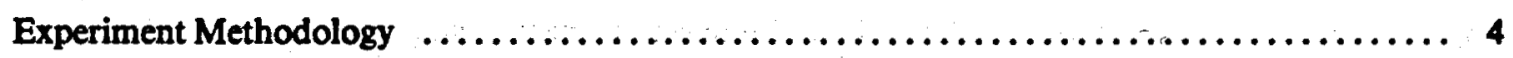

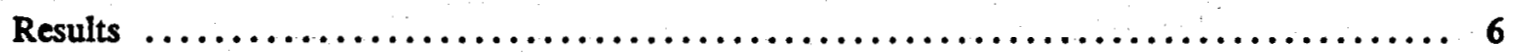

FLUIDIZED BED DRYER EXPERIMENT $\ldots \ldots \ldots \ldots \ldots \ldots \ldots \ldots \ldots \ldots \ldots \ldots \ldots \ldots \ldots, 6$

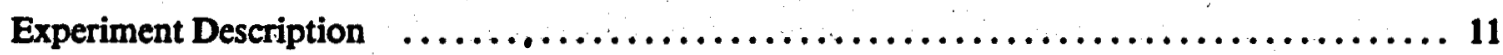

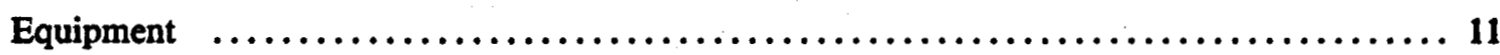

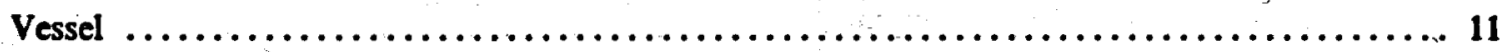

Product Removal $\ldots \ldots \ldots \ldots \ldots \ldots \ldots \ldots \ldots \ldots \ldots \ldots \ldots \ldots \ldots \ldots \ldots \ldots \ldots \ldots \ldots \ldots, 11$

Raw Product $\ldots \ldots \ldots \ldots \ldots \ldots \ldots \ldots \ldots \ldots \ldots \ldots \ldots \ldots \ldots \ldots \ldots \ldots \ldots \ldots \ldots \ldots \ldots \ldots, 14$

Experiment Observations and Results $\ldots \ldots \ldots \ldots \ldots \ldots \ldots \ldots \ldots \ldots \ldots \ldots \ldots \ldots \ldots, 14$

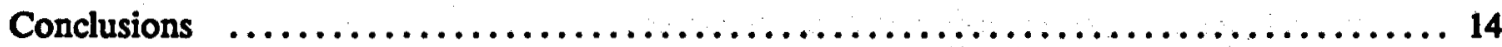

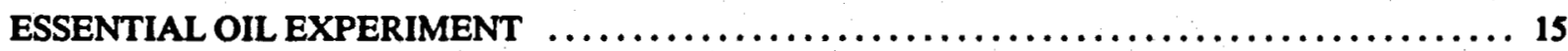

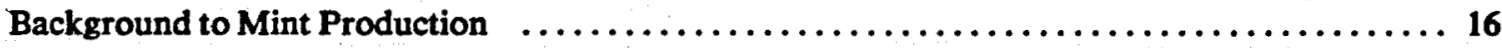

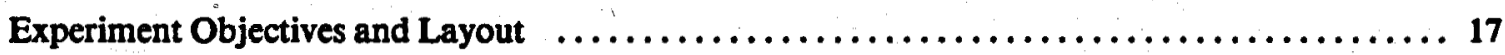

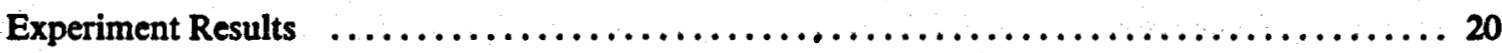

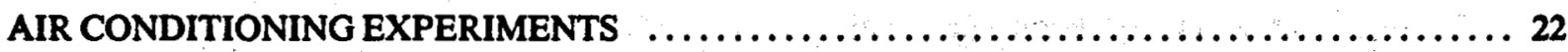

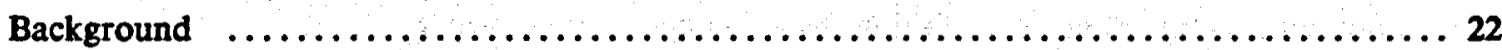

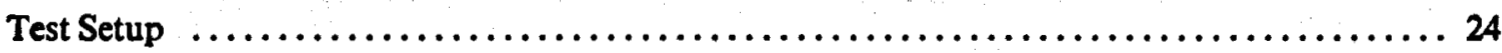

System Operation $\ldots \ldots \ldots \ldots \ldots \ldots \ldots \ldots \ldots \ldots \ldots \ldots \ldots \ldots \ldots \ldots \ldots \ldots \ldots \ldots \ldots, 24$

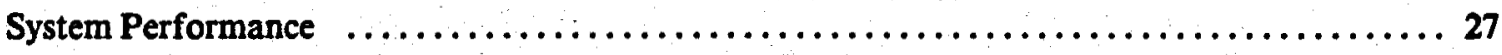

SMALL-SCALE ALCOHOL DEMONSTRATION $\ldots \ldots \ldots \ldots \ldots \ldots \ldots \ldots \ldots \ldots \ldots \ldots \ldots, 31$

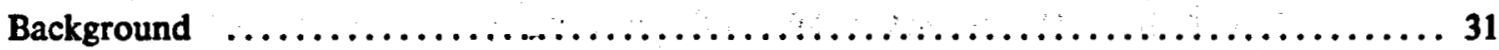




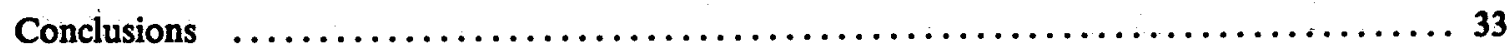

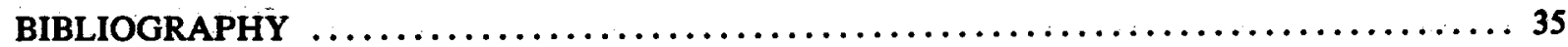

\section{FIGURES}

1. Schematic representation of fluidization as functionsof pressure drop

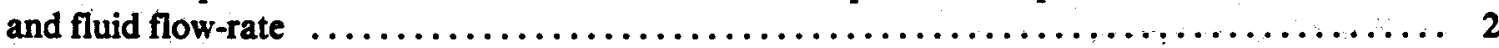

2. Diagram of a double pass, vertical, liquid fluidized-bed heat exchanger $\ldots \ldots \ldots \ldots \ldots \ldots \ldots 3$

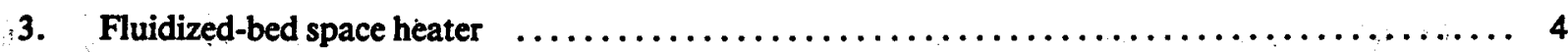

4. Crossflow pattern of primary water and secondary airstream $\ldots \ldots \ldots \ldots \ldots \ldots \ldots \ldots \ldots 6$

5. Fluidized-bed space heater heat output at various geothermal water and air flow rates and with different bed particle sizes $\ldots \ldots \ldots \ldots \ldots \ldots \ldots \ldots \ldots$

6. Fluidized-bed space heater heat output at various geothermal water and air flow rates and without a fluidized bed $\ldots \ldots \ldots \ldots \ldots \ldots \ldots \ldots \ldots \ldots \ldots$

7. Fluidized-bed space heater heat output as a function of water flow rate $\ldots \ldots \ldots \ldots \ldots \ldots$

8. Fluidized-bed space heater overall heat transfer coefficient at various geothermal water and air flow rates, different bed particle sizes,

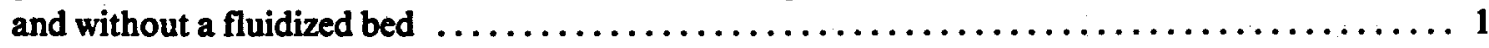

9. Fluidized-bed drying cycle using geothermal water in the tube

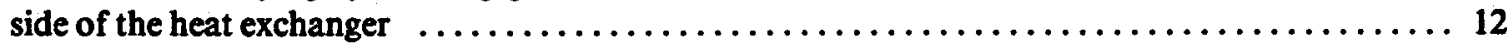

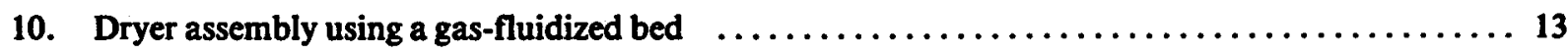

11. Schematic of equipment used for geothermal extraction of essential oils $\ldots \ldots \ldots \ldots \ldots \ldots$

12. Schematic of extraction equipment showing the scale and placement

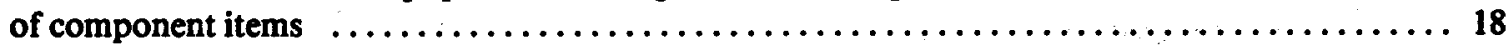

13. Photo of geothermal extraction equipment $\ldots \ldots \ldots \ldots \ldots \ldots \ldots \ldots \ldots \ldots \ldots \ldots \ldots$

14. Solution flow diagram of the lithium bromide and distilled water

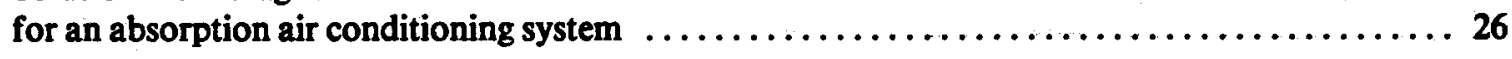

15. Design ducting schematic for air conditioner $\ldots \ldots \ldots \ldots \ldots \ldots \ldots \ldots \ldots \ldots \ldots \ldots \ldots \ldots \ldots \ldots \ldots \ldots$

16. Design piping schematic for air conditioner $\ldots \ldots \ldots \ldots \ldots \ldots \ldots \ldots \ldots \ldots \ldots \ldots \ldots \ldots$

17. Output cooling capacity as a function of generator inlet temperatures

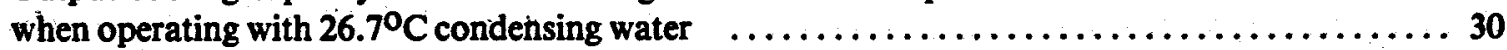

18. Block diagram showing the different steps in the production of pure $(99.9 \%)$ alcohol 
19. Flow diagram and equipment layout of the first phase of alcohol production (to $90 \%$ pure)

20. Small-scale geothermal demonstration plant

\section{TABLES}

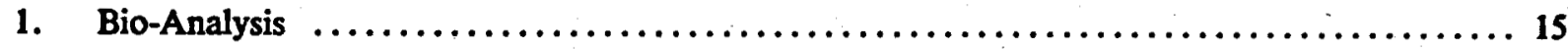

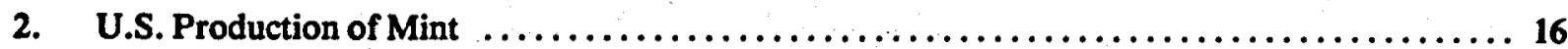

3. Water Chemistry of Wells Used in Extraction Process $\ldots \ldots \ldots \ldots \ldots \ldots \ldots \ldots \ldots \ldots \ldots$

4. Extraction Process Operational Parameters $\ldots \ldots \ldots \ldots \ldots \ldots \ldots \ldots \ldots \ldots \ldots \ldots \ldots \ldots \ldots$

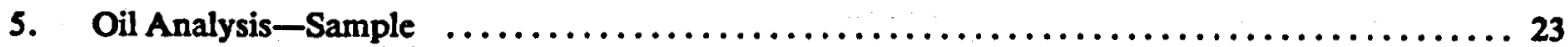




\section{SUMMARY}

This report summarizes geothermal direct applications components and systems development work performed at the Department of Energy's Raft River Geothermal Test Site during calendar year 1979. The work elements discussed herein are: (a) fluidized bed applications for space heating, (b) fluidized bed drying, (c) essential oil extraction, (d) conversion of biomass to ethanol, and (e) evaluations of air conditioning systems.

In each of these work tasks, geothermal fluids were used directly for the process heat. The space heat activity was aimed at developing a system for utilizing highly corrosive and scaling fluids; the geothermal drying was an extension of previous activities to include steam-peel potato materials; peppermint was used in the oil extraction work; sugar beet juices were successfully converted to alcohol in the first known application of geothermal heat to this process; and the air conditioning unit evaluations progressed from lithium bromide unit testing to planning for the acquisition and testing of a unit designed for efficient operation at source temperatures as low as $40.6^{\circ} \mathrm{C}$. 


\section{GEOTHERMAL DIRECT APPLICATIONS HARDWARE SYSTEMS DEVELOPMENT AND TESTING - 1979 SUMMARY REPORT}

\section{INTRODUCTION}

The direct applications components and systems development task is performed at the Department of Energy's Raft River Geothermal Test Site in Idaho to support the national hydrothermal direct applications commercialization plan. ${ }^{2}$ This task addresses beneficial uses of geothermal fluids, and hardware research and technology. Hardware research is aimed at investigating new and alternative hardware systems for geothermal direct applications commercialization or at modifying existing hardware technology to better utilize geothermal heat and fluids.

This report focuses on hardware system development and testing performed during calendar year 1979. Fluidized bed technology was applied to the drying of potato by-products and to the exchange of heat to air in the space heating experiment. Geothermal water was flashed to steam and utilized as the prime energy source in the steam distillation of peppermint oil. Geothermal water temperatures as low as $112.8^{\circ} \mathrm{C}$ were used to distill alcohol from sugar beet juice. Lower temperature geothermal water provided air conditioning through an absorption air conditioning system. These experiments are discussed in further detail in this report.

\section{FLUIDIZED BED HEATER EXPERIMENT}

The objective of this experiment was to examine the application of fluidized bed technology to space heating using low-to-moderate temperature, highly scaling geothermal water. If this technique can be applied, home owners and users of industrial process heat could use geothermal water whenever scaling, corrosion, or contamination are not conventionally tolerable.

a. A preliminary draft of the national hydrothermal direct applications program plan was being reviewed by DOE Division of Geothermal Resource Management and prepared for release at the time this report was in preparation.
This experiment utilized a fluidized bed heat exchanger originally designed as a water-to-water unit. This unit has been successfully tested at East Mesa in Imperial Valley, California.

Although not designed as a water-to-air exchanger, this unit was tested with and without a fluidized bed to compare any variations in overall heat transfer coefficients and heat output capacity. The overall heat transfer coefficient increased nearly 30 to $40 \%$, with a fluidizing bed present for similar air and geothermal flow rates. Similarly, heat output capacity increased 20 to $30 \%$ with the bed present and operating under similar circumstances.

The fluidized bed space heater, therefore, showed promising results. Heat transfer coefficient and heat output rates increased as a result of a fluidized bed. No corrosion was observed over the testing period.

\section{Fluidized Bed Technology}

The fluidized bed consists of a bed of solid particles with a fluidizing stream (Figure 1). Whenever fluid velocity is sufficient to apply a drag force on the particles equal to or greater than gravitational forces, the bed expands and the fluid-particle system behaves like a fluid. When the fluid velocity exceeds the particle settling velocity (terminal velocity), particles are entrained in the fluid and elutriated.

Liquid fluidized bed heat exchangers consist of four parts (Figure 2):

1. Flow distribution-support system. Geothermal flow through the bed must be uniform. Distribution is accomplished in the plenum by regulating the pressure drop across the distribution-support system, or by physically distributing the fluid with a manifold.

2. Fluidized bed. The bed of particles is contained by the shell, and the top of the 


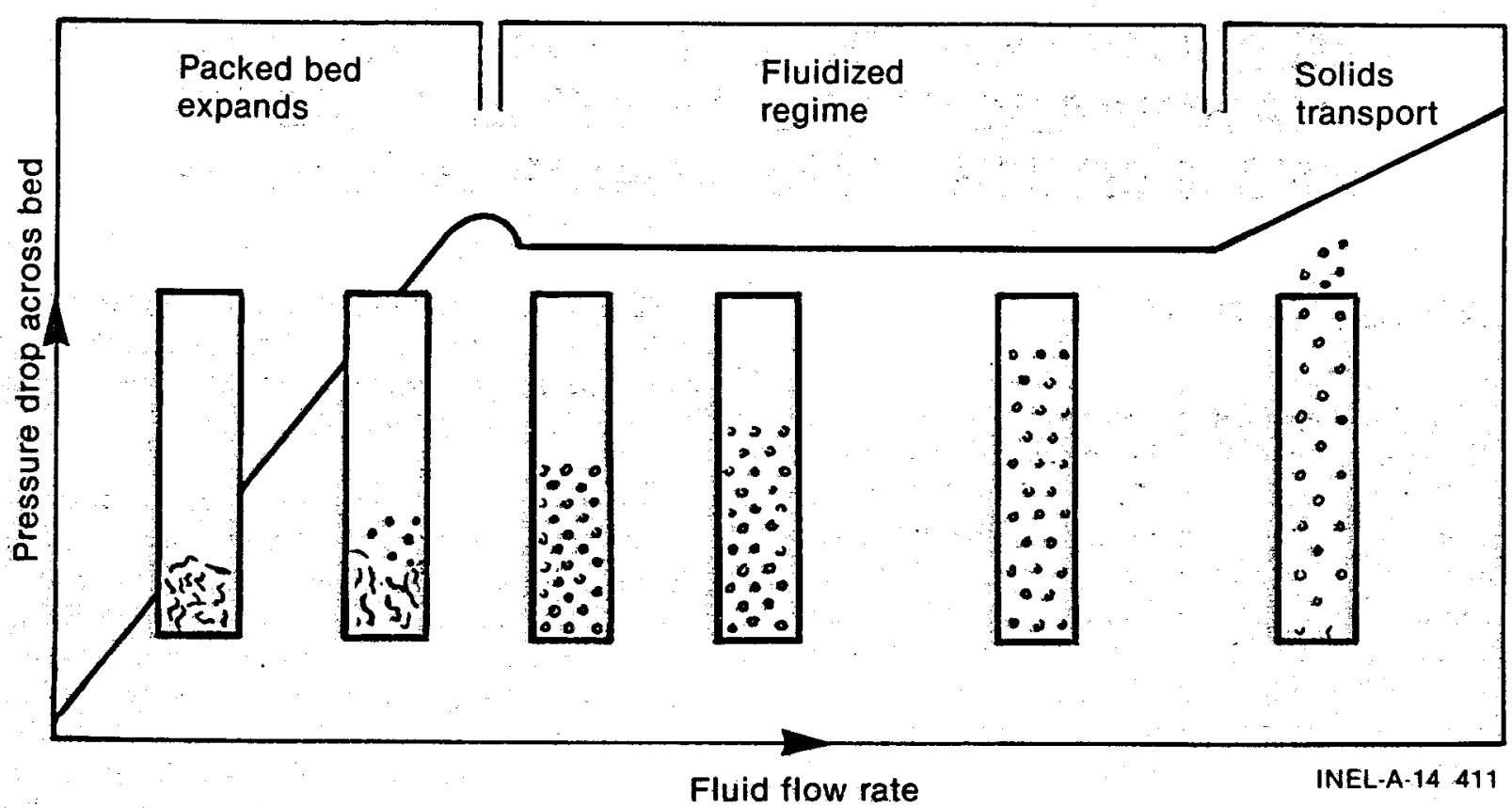

Figure 1. Schematic representation of fluidization as functions of pressure drop and fluid fow-rate.

bed is regulated by the quantity of bed material and the fluid velocity. Most commonly, the bed material consists of silica sand closely screened to the desired size.

3. Disengagement space. Between the top of the bed and the level of the geothermal outlet, a space must be allowed for particles to disengage from the fluid and fall back to the bed. Liquid fluidized beds normally exhibit a sharp interface at the top of the bed due to their particulate fluidization mechanism. As a result, the disengagement space can be much smaller than needed in gas fluidized beds.

4. Tube bundle. The secondary fluid or air stream flows through the tube bundle immersed in the bed.

The shell of liquid fluidized bed heat exchangers can be arranged either vertically as in Figure 2, or horizontally as in Figure 3. In either case, the geothermal fluid flows vertically through the bed on the shell side. The choice of horizontal versus vertical arrangement is based on mass flow rate, heat transfer surface requirements, cost, and physical limits.

The isothermal nature of fluidized bed heat exchangers is the primary characteristic that causes their design to differ from conventional units. This is due to the rapid mixing of bed particles. Because of this property, liquid fluidized bed heat exchangers must be staged to approach counter-current efficiency.

\section{Heat Transfer Mechanism}

Typically, heat transfer in fluidized beds is at least 1.5 times greater than that of a unit without a bed present. The increased heat transfer rates are believed to be the continual erosion of the thin film barrier surrounding the tubes and are related to the frequency of contact between particles and tubes. This in turn is related to the density of particles (porosity), particle size, and particle velocity. Both porosity and particle velocity are related to the fluid velocity.

\section{Potential Advantages}

Control of scale in geothermal systems provided the impetus for adapting and developing liquid fluidized bed heat exchangers. In geothermal systems the temperatures are low, and the ratio of surface area to heat transferred is high. Since most geothermal water has high scaling potential, heat exchangers must be designed to anticipate high fouling rates. Such designs are costly because of 


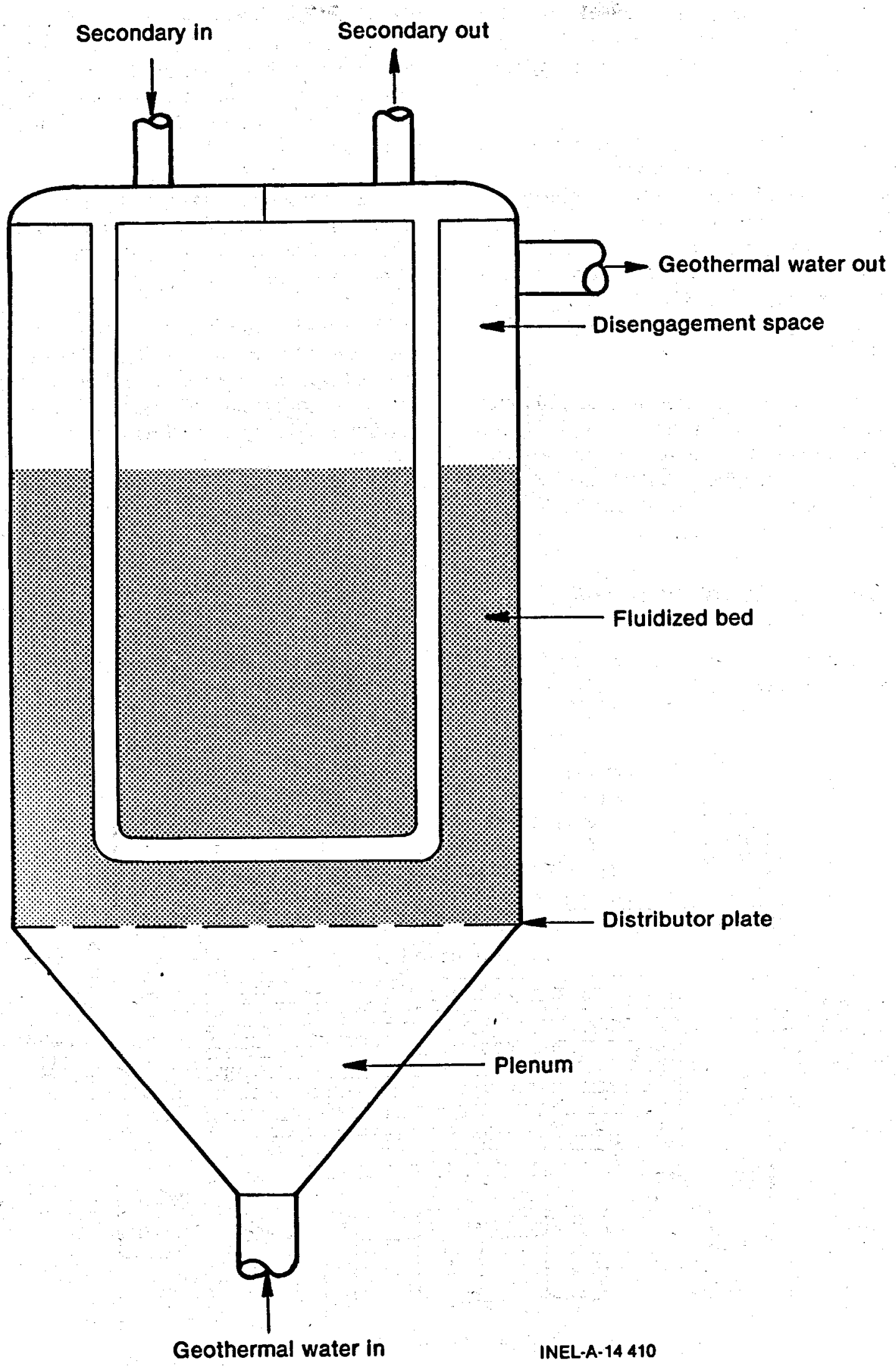

Figure 2. Diagram of a double pass, vertical, liquid fluidized-bed heat exchanger. 
the high cost of heat transfer surface. By reducing or eliminating scale deposits on heat exchanger surfaces, the economics of hydrothermal systems will be favorably altered.

The fluidized bed provides abrasive action to continually scrub the heat transfer surfaces. This mechanism was demonstrated by experiments at Raft River for the water-to-water exchanger tests. After 60 days of operation, the heat transfer surfaces were highly polished. Also, during experiments with silica and $\mathrm{CaCO}_{3}$ supersaturated solutions, neither the particles or the tube surface received deposit.

The surface area of the bed is about $\mathbf{5 0}$ times larger than heat transfer surface area. This area difference causes deposits to form on the bed particles rather than the heat transfer surface. This mechanism may be important for very hard deposits such as iron sulfide.

\section{Experiment Methodology}

The fluidized bed space heater used in this experiment was modified from an existing fluid- ized bed water-to-water heat exchanger. The modifications involved only the changes necessary to use air as the secondary medium rather than water. Figure 3 illustrates the heat exchanger modified to operate as a water-to-air heat exchanger.

The horizontal layout introduces some problems of cross flow and variable cross section. The variable cross section causes differing velocities within the shell.

The velocity at the bottom of the exchanger could exceed terminal velocity, while the top of the bed appears normal. It is imperative when designing horizontal exchangers to calculate the maximum velocity as well as the cross-sectional velocity.

Another problem created by cross flow in horizontal vessels is a region of very low velocity directly above a tube. In model units, streaming past the tubes creates a pile of particles resting on top of the tubes. These are dead areas as far as heat transfer is concerned, and are potential locations for corrosive attack. Two possible methods of eliminating this problem are to induce internal

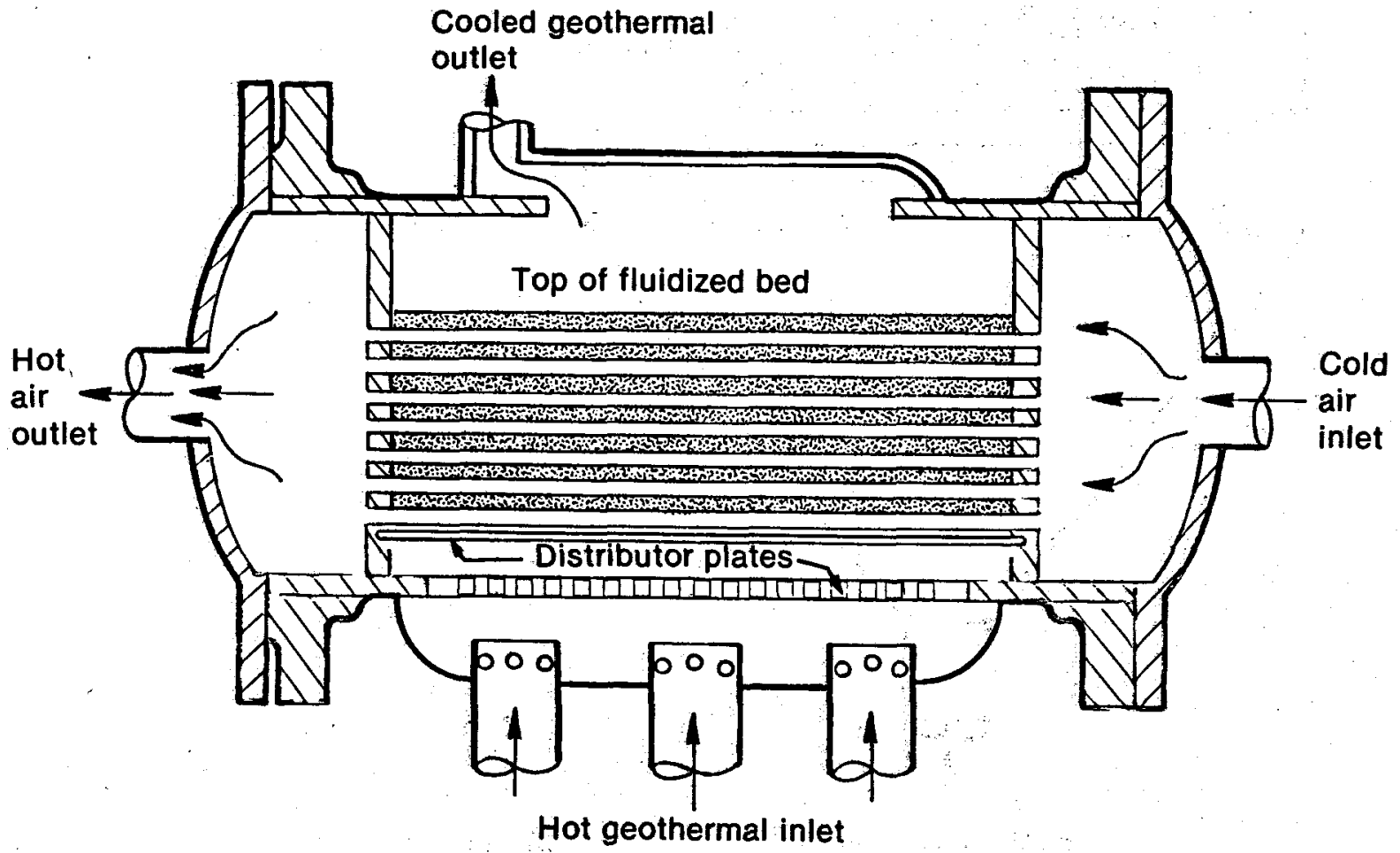

INEL-A-14 730

Figure 3. Fluidized-bed space heater. 
circulation by means of baffles, or to use spiral fluted tubing. These techniques have not been tested.

The heat exchanger was $45 \mathrm{~cm}$ long and $20 \mathrm{~cm}$ in diameter, and constructed of carbon steel with a $7.5-\mathrm{cm}$ view glass on each side of the vessel for observation of the fluidized bed. Thermocouples were located to measure temperature below, within, and above the bed. The tube bundle, constructed of 304 stainless steel, consisted of 57 tubes, each $0.95 \mathrm{~cm}$ in diameter and $35 \mathrm{~cm}$ long, on a 1.9-cm triangular pitch. Three slots were cut in the lower tube sheets parallel to the bottom end of tubes so that as many as three components could be used in the distributor plate, or a single distributor plate could be placed at any one of three positions. Slots were cut in the upper tube sheets so either a bed-retaining screen, or plates designed to improve geothermal flow could be used. A stainless steel bubble cap distributor plate was chosen for the most uniform fluid flow through the bed material. The average fluid velocity through the openings around the bubble caps was $4.7 \mathrm{~m} / \mathrm{min}$.

Temperature measurements were made with stainless steel clad J-type thermocouples placed at the geothermal and coolant water inlets and outlets, and at five locations within the fluidized bed. This allowed measurement of heat balances, bed temperatures, and bed temperature gradients. Thermocouples were calibrated at the ice point $\left(0^{\circ} \mathrm{C}\right)$ and water boiling point $\left(100^{\circ} \mathrm{C}\right)$. All thermocouples used in this experiment read within $\pm 1^{\circ} \mathrm{C}$ of these temperatures.

Turbine flow meters, calibrated by direct measurement of volume versus time, were used to measure air and geothermal water flows. The parameters measured for each flow calibration were volume and time. A Doric 220 data acquisition system, equipped with 40 input channels and a digital printout, recorded temperature in degrees Celsius or Fahrenheit for J-type thermocouples, or up to 4 volts output.

The heat exchanger consisted of 57 tubes, each $35 \mathrm{~cm}$ long and $0.95 \mathrm{~cm}$ in diameter. The heat transfer area was $5954.1 \mathrm{~cm}^{2}(A=2 \pi \mathrm{ln}$, where $n=$ number of tubes).

The overall heat transfer was calculated from the equation:
$\mathbf{Q}=\mathbf{U A F} \mathbf{T}_{\mathbf{m}}$

where

$$
\begin{aligned}
& \mathbf{Q}=\text { overall heat transfer } \\
& \mathbf{U}=\text { heat transfer coefficient } \\
& \mathbf{F}=\text { correction factor } \\
& \mathbf{T}_{\mathbf{m}}=\text { mean temperature. }
\end{aligned}
$$

Correction factors, F, were found using the graph in Figure 4.

Solving Equation (1) for $\mathrm{U}$

$\mathbf{U}=\frac{\mathbf{Q}}{\mathbf{A F T}_{\mathbf{m}}}$

The heat gained by the air may also be calculated from

$\mathbf{Q}=\mathbf{W} \mathbf{C} \Delta \mathbf{t}$

where

$$
\begin{aligned}
& W=\text { mass flow rate } \\
& \mathbf{C}=\text { thermal conductivity } \\
& \Delta t=\text { change in temperature. }
\end{aligned}
$$

Using the above equations, the overall heat transfer coefficients were calculated while controlling four variables: the geothermal water flow rate, air flow rate, geothermal water inlet temperatures, and air inlet temperatures. Values of the outlet temperatures are related by the law of energy conservation and the values of heat transfer coefficients.

Bed material was silica sand with mean particle diameters (MPD) of $2.0 \mathrm{~mm}$ and $1.0 \mathrm{~mm}$. Sand was added or deleted to maintain a bed level approximately $1 \mathrm{~cm}$ above the tube bundle. Geothermal velocities varied from 0.011 to $0.079 \mathrm{~m}^{3} / \mathrm{min}$, and air flow varied from 0.28 to $0.88 \mathrm{~m}^{3} / \mathrm{min}$. Thermal conductivity for air was assumed to remain constant at $7.005 \mathrm{~J} / \mathrm{g}^{\circ} \mathrm{C}$ and density $11.37 \mathrm{~kg} / \mathrm{m}^{3}$ for air outlet temperatures plus or minus $5 \%$ from $37.8^{\circ} \mathrm{C}$. The mean average temperature $\left(T_{m}\right)$ for Equation (2) was calculated from: 

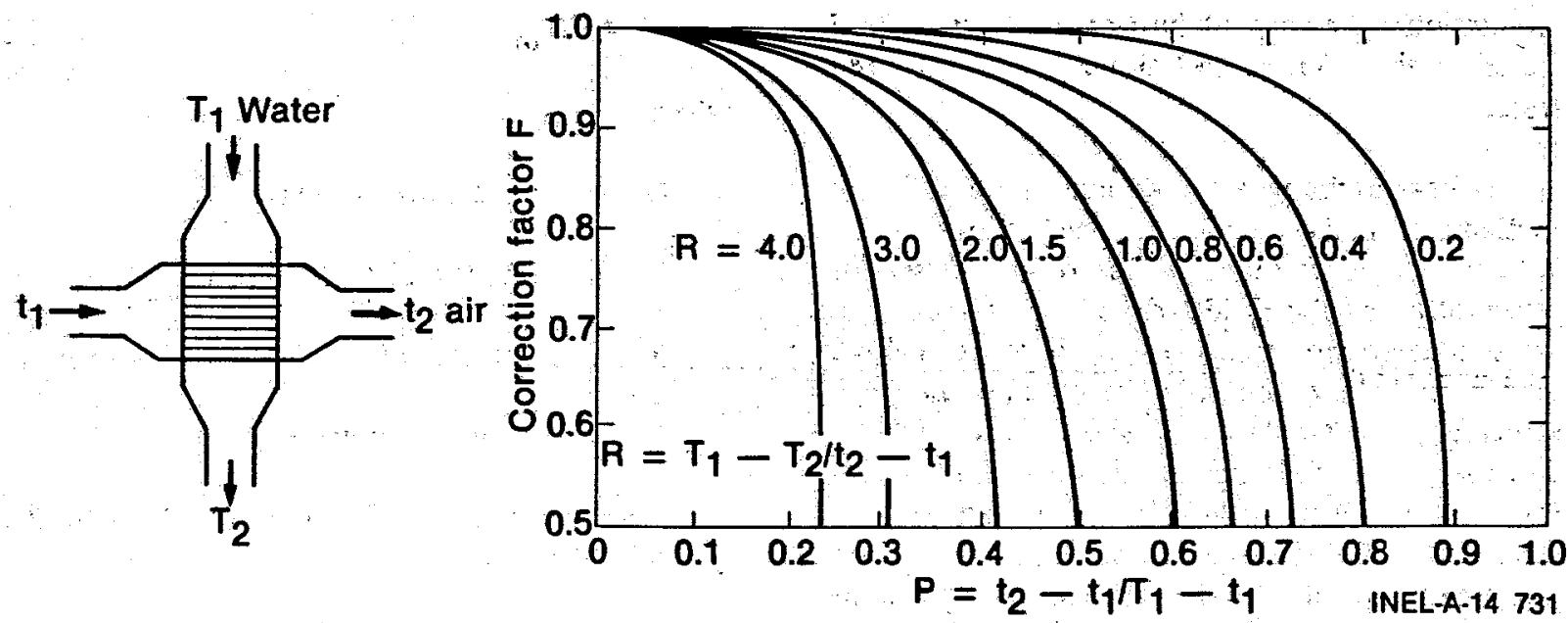

Figure 4. Crossflow pattern of prinary water and secondary airstream.

$T_{m}=\frac{\left(T_{1}-t_{2}\right)-\left(T_{2}-t_{1}\right)}{\ln \left(T_{1}-t_{2}\right)}$

\section{Results}

Heat output (air stream) was measured while independently varying the geothermal water flow rate and the air stream flow rate. The heat output is biased in favor of the air stream flow. As can be seen in the graph in Figure 5, increases in air stream flow rate directly affect the heat output, while changes in geothermal flow rate show virtually no change in heat output. This can be seen especially well with low geothermal flow rates. Increases in heat output do occur with increasing geothermal flow rate; however, once fluidization occurs and bed isothermal conditions are established, almost no change in heat output occurs. Note that for the smaller particles $(1.0 \mathrm{~mm}$ MPD), fluidization occurs earlier, and no change of heat output was recorded for varying geothermal flow rate at constant air stream velocities.

The test without a bed material present showed nearly a $20 \%$ reduction in heat output for any given geothermal flow rate. Higher flow rates showed greater reduction in heat output. Without a bed present, the highest air flows showed reduced heat output with increasing water flows resulting from air turbulence.

Figure 6 further illustrates the heat output's dependence on air flow rate. Increasing the geothermal water flow rate from $0.011 \mathrm{~m}^{3} / \mathrm{min}$ to $0.057 \mathrm{~m} / \mathrm{min}$ produces only a small increase $(10 \%)$ in heat output. Further increases up to $0.079 \mathrm{~m}^{3} / \mathrm{min}$ of geothermal water show virtually no increase in heat output.

Intermittent test operation was conducted over a period of several months. Any corrosion that resulted during long periods of downtime under oxygenated conditions (heat exchanger drained and open to the atmosphere) completely disappeared after start-up.

As shown in Figures 7 and 8, both heat output and overall heat transfer coefficient increase with increasing air flow rates for any given geothermal flow. Tests with and without a fluidizing bed revealed a 29 to $38 \%$ increase in overall heat transfer coefficient and a 20 to $29 \%$ increase in overall heat output capacity.

\section{FLUIDIZED BED DRYER EXPERIMENT}

The fluidized bed dryer experiment during calendar year 1979 was a continuation of more extensive work performed during $1978 .^{\text {a }}$ During 1978 tests were performed on two product materials-caustic potato peel and activated biomass secondary treatment potato waste. The 1979 tests were performed on steam potato peel.

a. L. T. Cole and R. C. Schmitt, "Fluidized Bed Dryer Experiment," (to be published). 


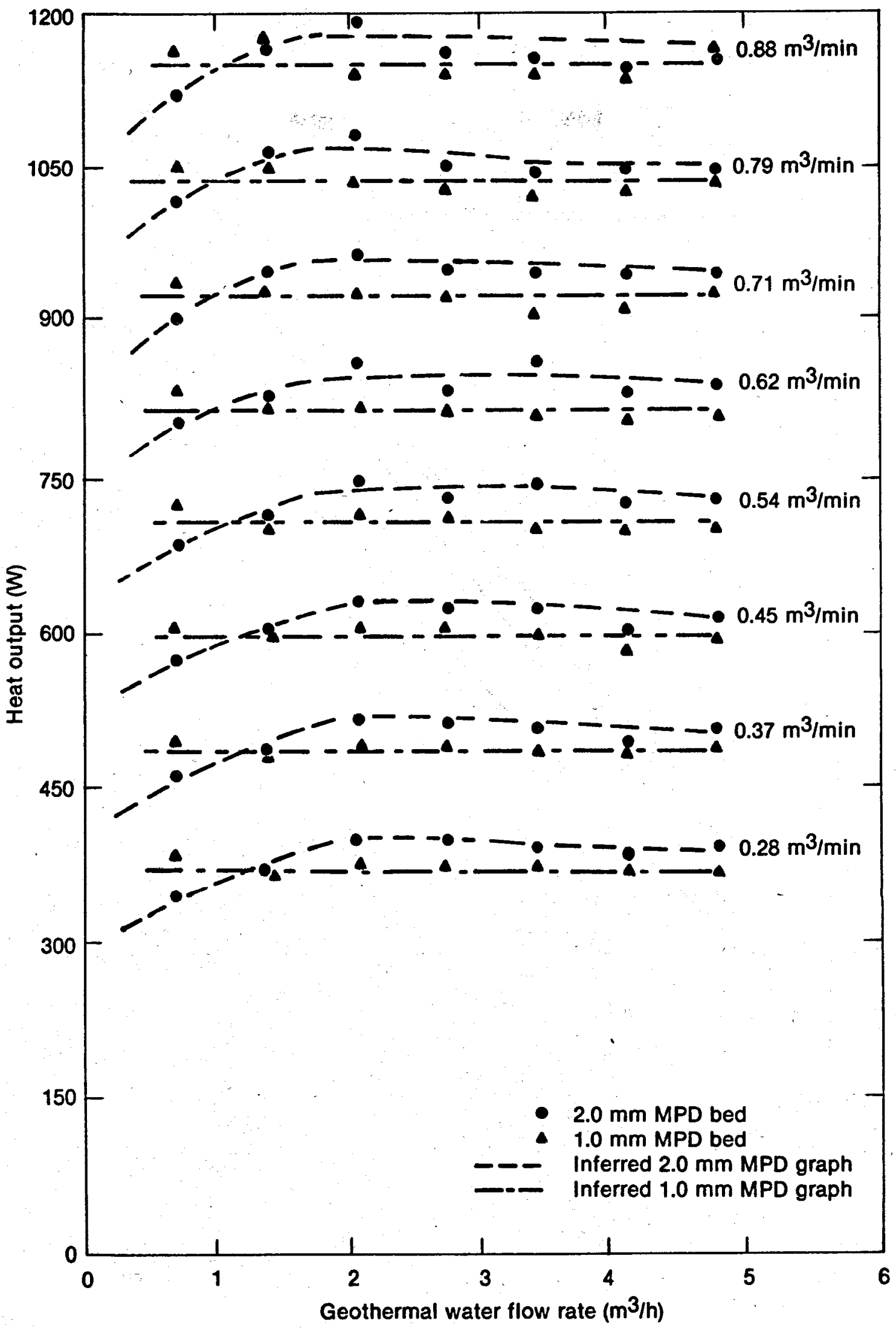

Flgure 5. Fluidized-bed space heater heat output at vartous geothermal water and air now rates and with different bed particle sizes. 


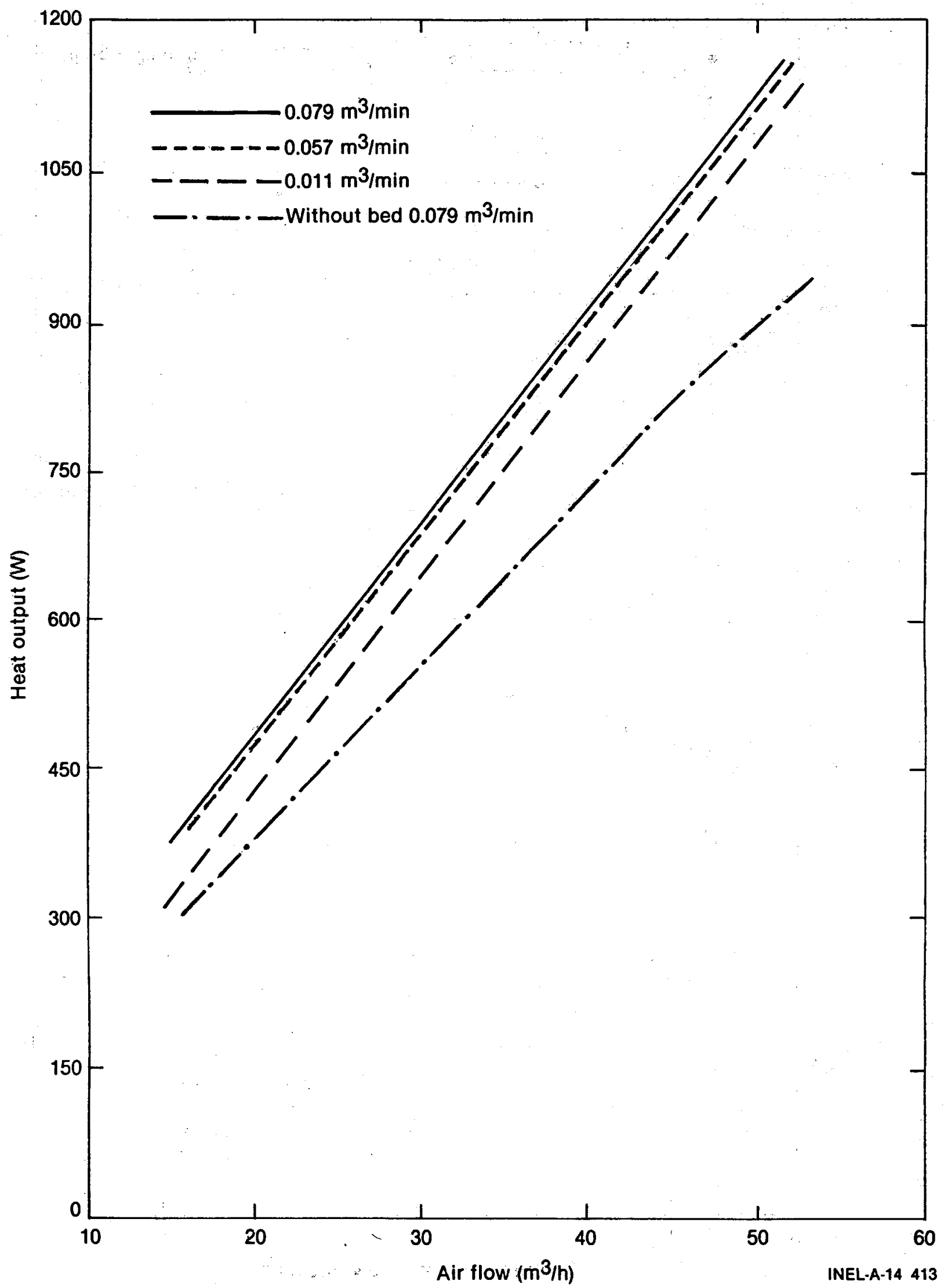

Figure 6. Fuldized-bed space heater heat output at various geothermal water and air flow rates and without a nuidized bed. 


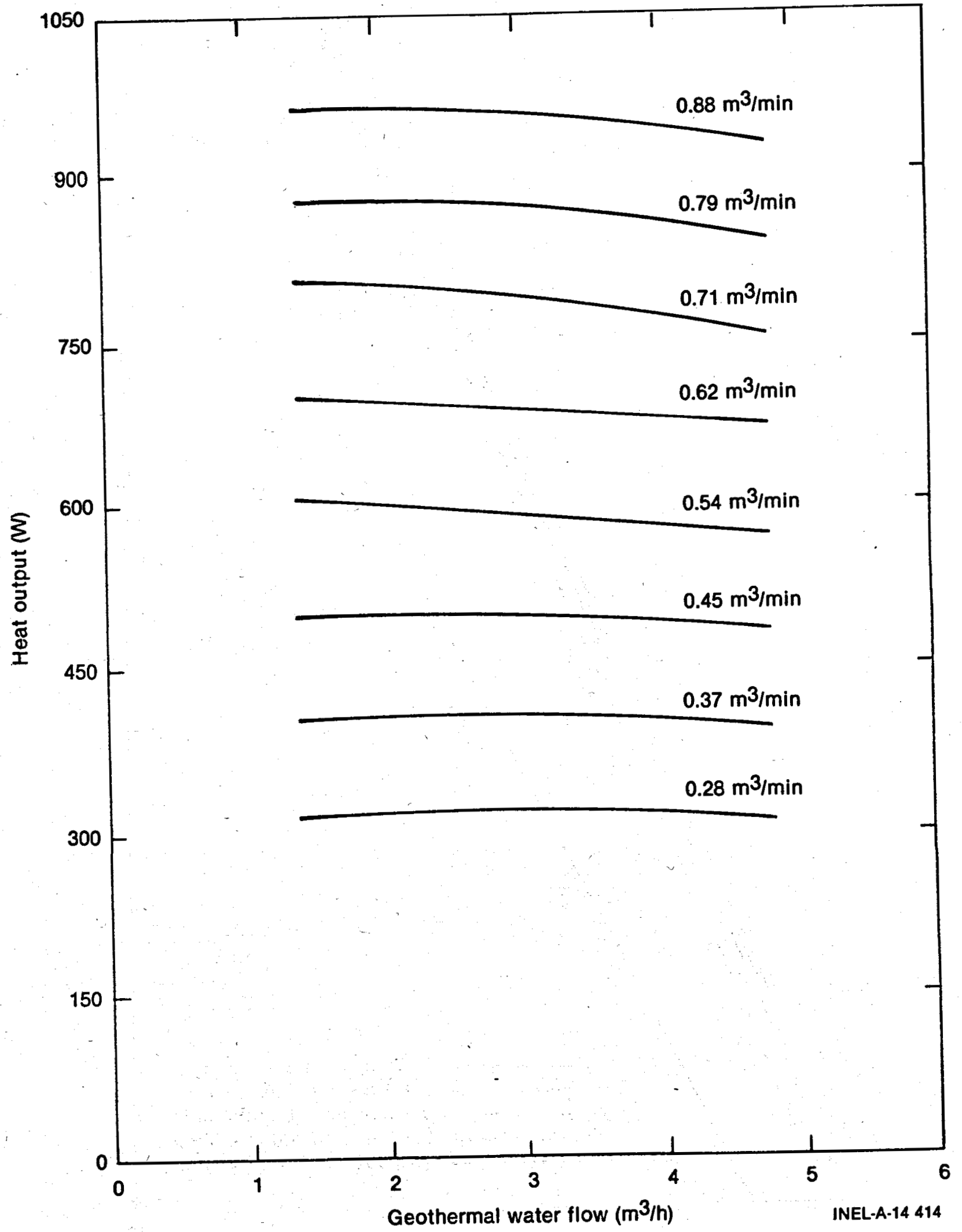

Figure 7. Fuidized-bed space heater heat output as a function of water flow rate. 


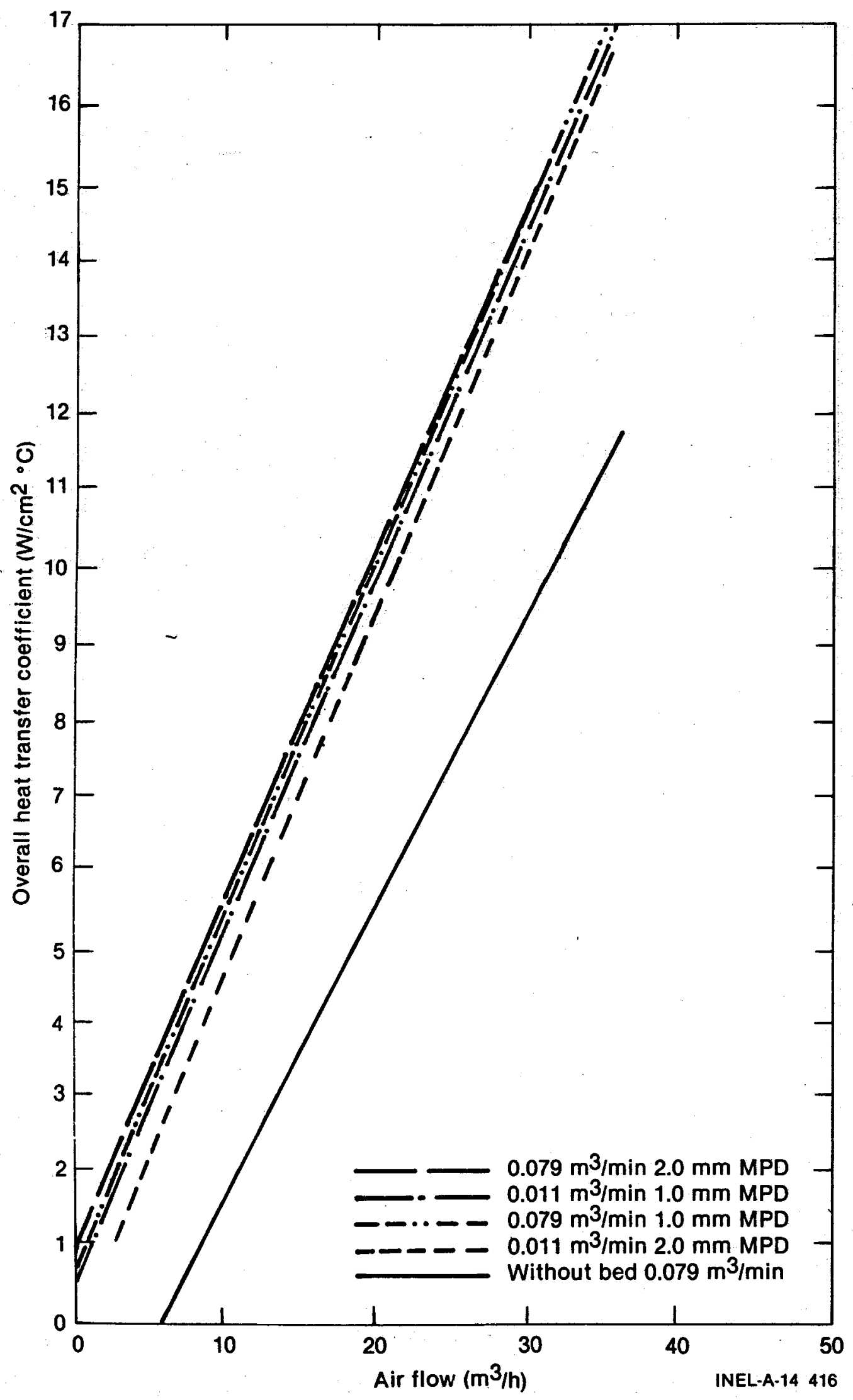

Figure 8. Fluidized-bed space heater overall heat transfer coefficient at various geothermal water and air now rates, different bed particle sizes, and without a fiuldized bed. 
Modifications to the existing equipment increased the product output rate for the 1979 tests. The principal results of the 1979 work were:

1. Geothermally dried steam peel material showed similar protein content and required similar dryer operating conditions as the caustic dry peel material

2. Product output rate improved, and losses decreased with the addition of a venturi to recycle dried product.

Many process industries have waste products that are valuable for protein or for fertilizer. However, these waste products must be dried for storage and to reduce weight and volume for transportation. This need prompted the development of an experimental dryer for the 1978 work. This dryer, based on the fluidized-bed principle, used geothermal hot water as the heat source. Initial drying tests were performed on two kinds of waste products from the potato processing industry as mentioned above. The potato waste materials were provided by the J.R. Simplot Company, a large Idaho potato processing firm and a participant in this experiment. The successful operation of this dryer, designed to use a geothermal heat source to dry a slurry-like input, demonstrated the potential for drying many industrial products in liquid form. The fluidizedbed dryer design is one of many possible designs, and is not proposed as the only acceptable process. However, the fluidized-bed dryer concept does show great promise for industrial drying projects, as demonstrated by this experimental dryer.

\section{Experiment Description}

The dryer developed in 1978 for this study used the concept of a gas-fluidized bed ${ }^{\mathrm{a}}$ for the drying process. The cycle shown in Figure 9 uses geothermal water in the tube side of the heat exchanger bundle. $A$ bed of dried material is fluidized by an air column around the tubes in the heat exchanger. The fluidized bed design allows excellent heat transfer from the heat exchanger tubes and provides excellent mixing characteristics to give an isothermal medium in the bed. The hot isothermal bed is used to dry slurry materials by spraying an

A. L. T. Cole and R. C. Schmitt, "Fluidized Bed Dryer Experiment," (to be published). atomized mist of the material into the bed. The atomized material dries almost instantly upon contact with the bed, and the dried product is removed by a simple gravity-fed overflow tube. The heated air, steam, and dust-like fines exit the dryer through the top and are routed to a cyclone separator to remove the fines before venting to the atmosphere. The addition of a venturi to the cyclone output was the major modification to the existing experiment during 1979.

\section{Equipment}

The dryer assembly for this experiment used a gas-fluidized bed, which is a system often used for product drying. The heat source, however, was from hot geothermal fluid, which is unique to the experiment.

\section{Vessel}

The dryer vessel, shown in Figure 2, stands approximately 8 feet tall, including all connections. The vessel is basically a vertical section of $25 \times 25-\mathrm{cm}$ rectangular structural tubing, with a distributor plate located in the bottom end to distribute fluidizing air to the bed material housed by the vessel. The tubing wall is adapted to accept two heat exchange bundles to provide heat for the drying operation. The fluidizing air and moisture removed during the drying process exit the dryer through a $5.1-\mathrm{cm}$ pipe located at the top of the vessel. The dryer is supported by an angle iron stand (not shown). The vessel wall is tapped to accept an atomizing nozzle which sprays the wet product into the vessel.

\section{Product Removal}

As raw product is added and dried, the fluidized-bed level rises. When the level rises sufficiently, the dried product is removed by gravity flow out of a $3.8-\mathrm{cm}$ diameter tube, as shown in Figure 10. This tube directs the granular product to a storage container, which is slightly pressurized to prevent moist fluidizing air from coming in contact with the stored material.

Dried product which is elutriated by the exiting air stream is removed by a cyclone separator. This product can then be used as is, or reinjected to the bed to allow further particle growth. 


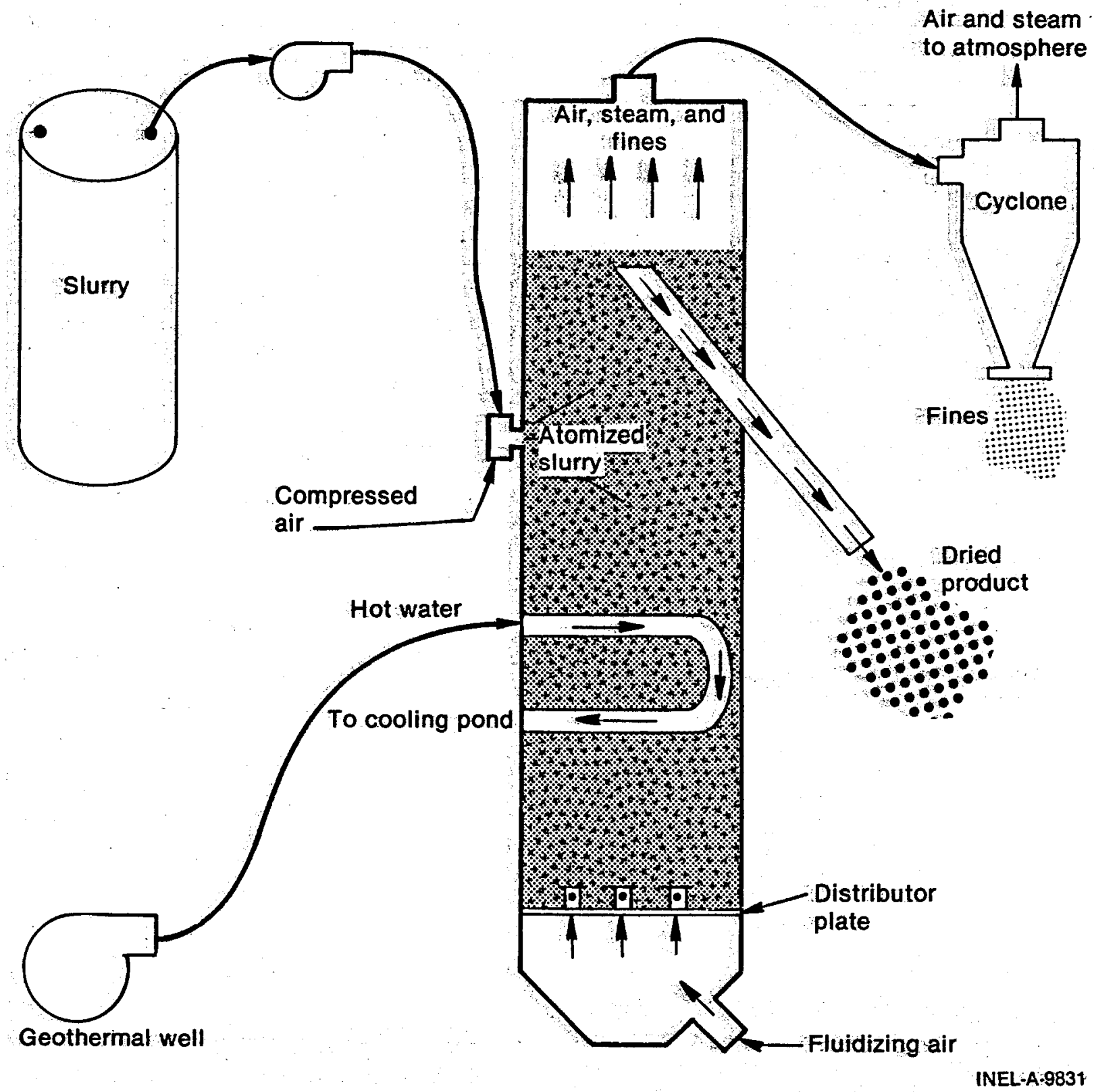

Figure 9. Fuidized-bed drying cycle using geothermal water in the tube side of the heat exchanger. 


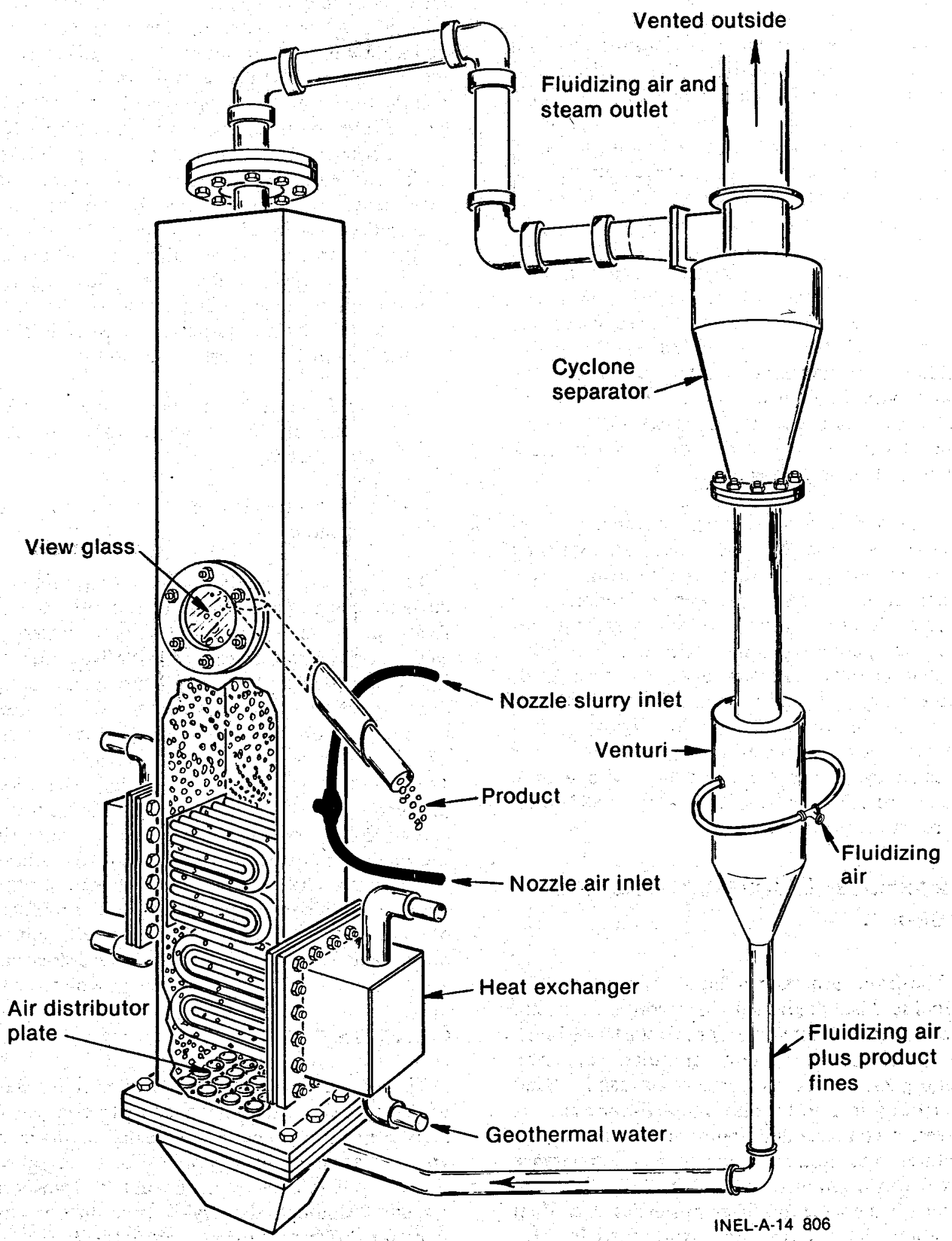

Figure 10. Dryer assembly using a gas-fluidized bed, 


\section{Raw Product}

The dryer will dry any material in slurry form which can be pumped through the atomizing nozzle without clogging, and which can be broken into an atomized mist by the nozzle air stream. Many materials may need to be uniformly sized and broken up prior to being sprayed through the nozzle, by use of a device such as a colloid mill or an in-line grinder for larger scale operations.

A part of the 1978 drying experiment was done with dry-peel potato waste, which is common to potato processors. Potatoes are dipped in a caustic solution to loosen the peels and then put through a rolling drum to remove the loosened peels. The slurry output of this drum had a bulk density of $0.9 \mathrm{~g} / \mathrm{cm}^{3}$, and was approximately $13 \%$ solids. The slurry had a viscosity of $42000 \mathrm{cP}$ (centipoise) at room temperature.

A second, more spoilable, activated biomass material was also dried. This material, consisting of a bacteriological single-cell protein, results from secondary waste treatment operations. The biomass is known to have 50 to $60 \%$ protein content, as opposed to grass, which has 10 to $15 \%$ protein content. The biomass was concentrated, prior to drying from its initial $0.5 \%$ solids content to 5 to $8 \%$ solids content, by large-scale centrifuges. After concentration, the slurry had a consistency of chocolate pudding, with a bulk density of $1.0 \mathrm{~g} / \mathrm{cm}^{3}$ and a viscosity of $80000 \mathrm{cP}$ at room temperature.

\section{Experiment Observations and Results}

The drying process in a fluidized bed requires an initial seed bed to give a drying medium. There are many potential candidates for this starter bed such as grass seeds, potato granules, or even nonorganic substances such as sand. Sand material was used for all tests performed at Raft River. A complete description of experiment procedures and results is given in the reference previously footnoted. Although the drying procedure is the same for different slurries, each final product will have its own particle size characteristics. The particle size is also dependent on the operating conditions of the dryer. The earlier tests with caustic dry peel and biomass materials revealed that a large percentage of product was being vented to the atmosphere. This resulted in a lower overall product output rate and an increase in the time necessary for bed displacement (when product displaces the initial sand bed and the final product becomes relatively sandless). The addition of a venturi, as shown in Figure 10, was instrumental in eliminating these problems. Fluidized air was introduced into the venturi and then delivered to the bottom of the bed for fluidization. The movement of the air through the venturi caused a relative negative pressure zone at the pipe connected to the cyclone. This negative pressure promoted a pulling effect for the fines material at the cyclone output. The net result from the addition of the venturi was twofold:

1. An increase in product output through reduction in product loss to the atmosphere

2. A decrease in time required for bed displacement.

The 1978 tests used the caustic potato peel and an activated biomass material. The current test focussed on a steam potato peel material. Potatoes are placed in contact with live steam to loosen the peels and then put through a rolling drum to remove the loosened peels. The peel material was obtained from the America Potato Company and stored in 50-gallon drums in cold storage conditions to await processing. The dried product was then analyzed for protein content, and typical values are shown in Table 1. Analysis was made both before and after drying to examine any changes. The most significant change was the increase in ash content attributable to the addition of sand particles from the fluidizing bed. Subsequent samples would show a steadily decreasing ash content until all of the bed had been displaced.

\section{Conclusions}

The gas-fluidized-bed dryer is an effective way of drying a slurry-like raw product to a very low moisture content. The product exits the dryer in granular form or in a powder-like form called fines, and is conducive to pneumatic transport systems. Although the drying procedure is the same for different slurries, each finished product will have its own particle size characteristics. The particle size is also dependent on the operating conditions of the dryer. 
TABLE 1. BIO-ANALYSIS

\begin{tabular}{|c|c|c|c|c|c|c|}
\hline \multirow[b]{2}{*}{$\begin{array}{c}\text { Composition } \\
(\%)\end{array}$} & \multicolumn{2}{|c|}{ Biomass } & \multicolumn{2}{|c|}{ Caustic Dry Peel } & \multicolumn{2}{|c|}{ Steam Peel } \\
\hline & $\begin{array}{l}\text { Wet } \\
\text { slurry }\end{array}$ & $\begin{array}{l}\text { Dried } \\
\text { Product }\end{array}$ & $\begin{array}{l}\text { Wet } \\
\text { slurry }\end{array}$ & $\begin{array}{l}\text { Dried } \\
\text { Product } \\
\end{array}$ & $\begin{array}{l}\text { Wet } \\
\text { Slurry }\end{array}$ & $\begin{array}{l}\text { Dried } \\
\text { Product } \\
\end{array}$ \\
\hline Crude protein & 1.7 & 44.9 & 1.7 & 11.9 & 1.9 & $5.1^{\mathrm{a}}$ \\
\hline Total N & 0.26 & 7.19 & 0.27 & 1.91 & 0.3 & 0.81 \\
\hline Crude fat & 0 & 0.6 & 0 & 0 & 0.1 & 0.4 \\
\hline Crude fiber & 0.2 & 2.7 & 0.8 & 5.0 & 0.7 & 1.1 \\
\hline Ash & 0.3 & 25.0 & 2.2 & 26.0 & 0.8 & $71.0^{b}$ \\
\hline $\begin{array}{l}\text { Nitrogen free } \\
\text { extract (NFE) }\end{array}$ & 3.4 & 24.1 & 9.4 & 56.0 & 12.7 & 20.9 \\
\hline $\begin{array}{l}\text { Total digestible } \\
\text { nutrient (TDN) }\end{array}$ & -- & -- & 10.1 & 59.2 & 13.3 & 23.3 \\
\hline Dry matterc & 5.6 & 97.4 & 14.1 & 98.9 & 16.2 & 98.5 \\
\hline Moisture & 94.4 & 2.6 & 85.9 & 1.1 & 83.8 & 1.5 \\
\hline \multicolumn{7}{|c|}{ Totals may not add to $100 \%$ without complete analys is } \\
\hline $\begin{array}{l}\text { a. May be low due } \\
\text { b. Analysis made } \\
\text { c. Dried material } \\
\text { possible. }\end{array}$ & $\begin{array}{l}\text { to high } \\
\text { arly aft }\end{array}$ & $\begin{array}{l}\text { h content } \\
\text { start-up }\end{array}$ & $\begin{array}{l}\text { after te } \\
\text { and ther }\end{array}$ & start-c & er ash & ontent. \\
\hline
\end{tabular}

The bed side heat transfer coefficient occurring at the heat exchange tube surface is a strong function of fluidizing air velocity. Maximum heat transfer coefficients of $160 \mathrm{~W} / \mathrm{m}^{2}-\mathrm{K}$ were observed during testing of the dryer. The velocity at which the maximum occurs is dependent on the material being dried.

A properly designed fluidized-bed dryer can turn some of industry's waste products into valuable, saleable products.

\section{ESSENTIAL OIL EXPERIMENT}

Essential oils are volatile flower and vegetable oils of which there are hundreds of different types. These oils are extractd from the plant tissue by solvent extraction or steam distillation and used in the perfumery and flavor industries. The objective of the essential oil extraction experiment was to demonstrate the use of geothermal steam in a typical oil extraction process and to determine the 
effect that geothermal steam might have on quality or flavor characteristics of the product. The production of peppermint oil was examined in this experiment; however other oils such as sage, cumin, corriander, spearmint, dill, etc. could be expected to behave in much the same way. The experiment was highly successful in the production of mint oil, and no adverse effect on quality or flavor was recorded.

\section{Background to Mint Production}

Mint crops (peppermint and spearmint) are produced to a large extent in the Northwestern U.S. and to a lesser extent in Michigan and parts of Illinois. Mint crops thrive mainly around the 45th parallel, where warm summer days and cool nights exist. The majority of peppermint and spearmint is grown in Oregon's Williamette Valley and Madrus areas, and in the Snake River Plain areas near Boise, Idaho and Ontario, Oregon. Idaho, in particular, provides 12 to $13 \%$ of the total U.S. demand for spearmint and 11 to $12 \%$ of the U.S. peppermint. Table 2 indicates the estimated 1979 mint production.

Mint oil is currently produced by each grower distilling his own crop and selling the oil to either a blender/refiner or directly to the end user. The nearby location of geothermal resources and mint growing areas is highly compatible. Geothermal resources are prevalent in mint growing areas and could be used as the steam source in a steam distillation process. The geographical match between geothermal resource and user indicates this activity could benefit a significant fraction of the total industry. The quality and flavor of the oil produced in direct contact with geothermal steam is of critical concern. Quality and flavor of the mint oil are the sole factors by which these oils are judged and sold.

TABLE 2 U.S. PRODUCTION OF MINTA

\begin{tabular}{|c|c|c|c|c|}
\hline & State & $\begin{array}{l}\text { Area Harvested } \\
(\times 1000 \mathrm{ha}) \\
\end{array}$ & $\begin{array}{l}\text { Yield } \\
\text { per ha } \\
\text { (kg of oil) }\end{array}$ & $\begin{array}{l}\text { Production } \\
(\times 1000 \mathrm{~kg}) \\
\end{array}$ \\
\hline \multicolumn{5}{|c|}{ Peppermint } \\
\hline & $\begin{array}{l}\text { Idaho } \\
\text { Indiana } \\
\text { Oregon } \\
\text { Washington } \\
\text { Wisconsin } \\
\text { U.S. }\end{array}$ & $\begin{array}{r}3.4 \\
3.4 \\
22.3 \\
5.5 \\
3.6 \\
38.2\end{array}$ & $\begin{array}{l}67.2 \\
40.3 \\
58.3 \\
67.2 \\
40.3 \\
57.2\end{array}$ & $\begin{array}{r}231.3 \\
137.0 \\
1297.3 \\
370.1 \\
146.9 \\
2182.7\end{array}$ \\
\hline \multicolumn{5}{|c|}{ Spearmint } \\
\hline & $\begin{array}{l}\text { Idaho } \\
\text { Indiana. } \\
\text { Michigan } \\
\text { Washington } \\
\text { Wisconsin } \\
\text { U.S. }\end{array}$ & $\begin{array}{l}1.6 \\
2.0 \\
1.6 \\
6.7 \\
1.8 \\
13.76\end{array}$ & $\begin{array}{l}67.2 \\
42.6 \\
33.6 \\
76.2 \\
53.8 \\
62.8\end{array}$ & $\begin{array}{r}108.8 \\
84.4 \\
54.4 \\
515.3 \\
95.7 \\
858.6\end{array}$ \\
\hline \multicolumn{5}{|c|}{$\begin{array}{l}\text { a. The } 1979 \text { forecast for peppermint is } 2.18 \text { million } \mathrm{kg} \text {, and spearmint is } \\
0.86 \text { million } \mathrm{kg} \text { (a } 42 \% \text { decrease from } 1978 \text { ). Source: USDA Idaho Crop and } \\
\text { Livestock Reporting Service, August } 14,1979 \text {. }\end{array}$} \\
\hline
\end{tabular}




\section{Experiment Objectives and Layout}

The prime objectives were to demonstrate the use of geothermal steam in a typical oil extraction process and to determine whether the geothermal resource would alter flavor or quality of the oil. Specific objectives were:

1. To establish geothermal application in the essential oil industry

2. To analyze the quality of essential oils produced from direct contact with geothermal steam

3. To gain expertise in the steam distillation process that would be useful to other industrial processes.

(n)

Equipment for the experiment was obtained as basically off-the-shelf units from a local sheet metal shop. Figure 11 indicates the major pieces of equipment. Geothermal water is flashed to lowpressure steam and fed into a steamer cart. Several 1.9-cm aluminum steam pipes emit steam into this cart which is loaded with the peppermint plant material to be processed. The geothermal steam removes the peppermint oil from the material whereafter both the oil and steam are condensed. A receiver vessel then separates the oil (lower density). Figure 12 shows the scale and placement of component items to minimize steam line length.

Standard essential oil equipment was purchased for the steam distillation units since the use of commercial equipment normally has greater acceptability by the private sector over laboratory bench-scale setups. The steamer cart, condenser, and receiver vessel were made of aluminum.

Due to the experimental nature of the activity, processing of the 0.4-ha crop could not be rapidly accomplished. This experimental nature required that the peppermint crop be preserved for a period

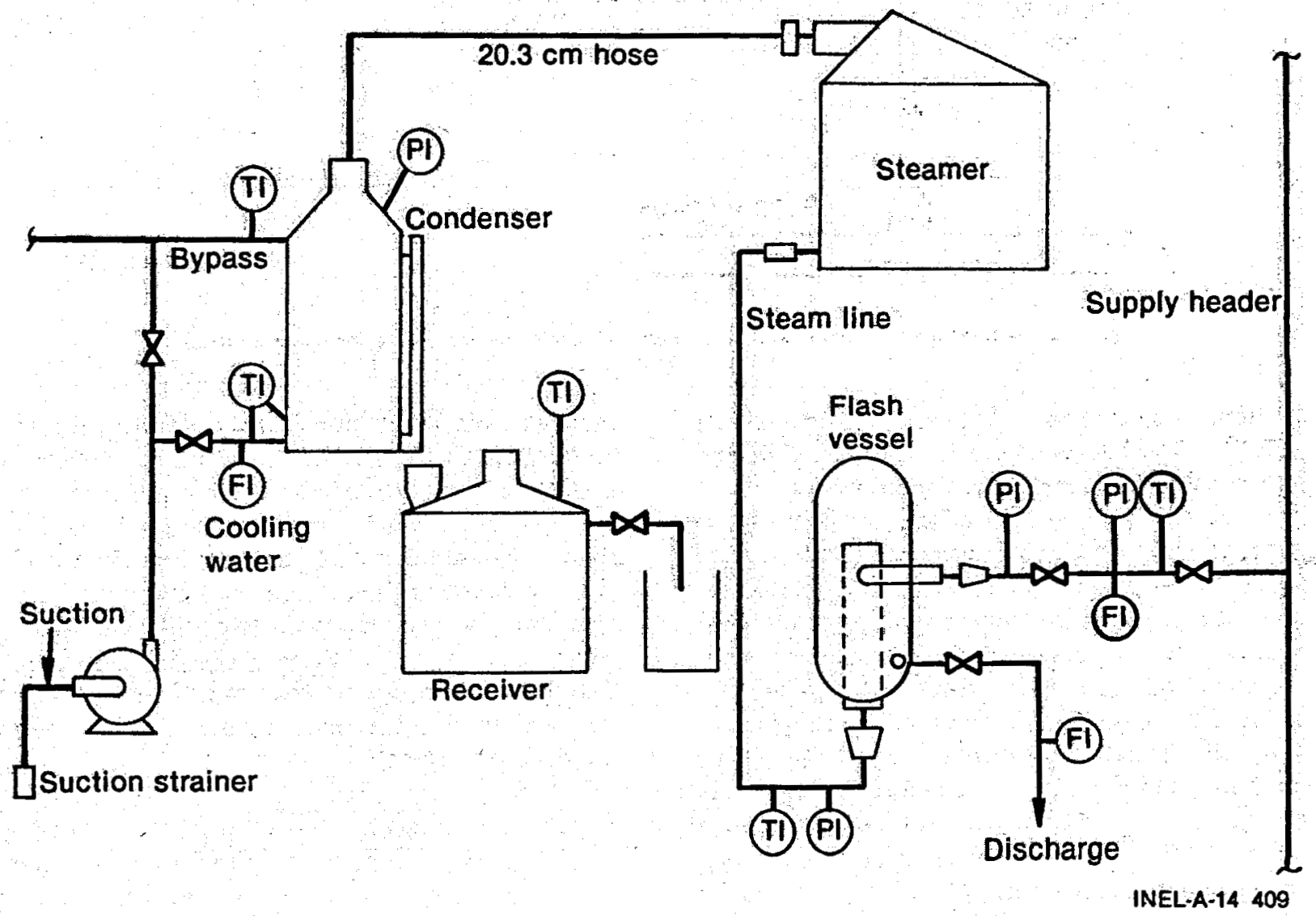

Figure 11. Schematic of equipment used for geothermal extraction of essential olls. 


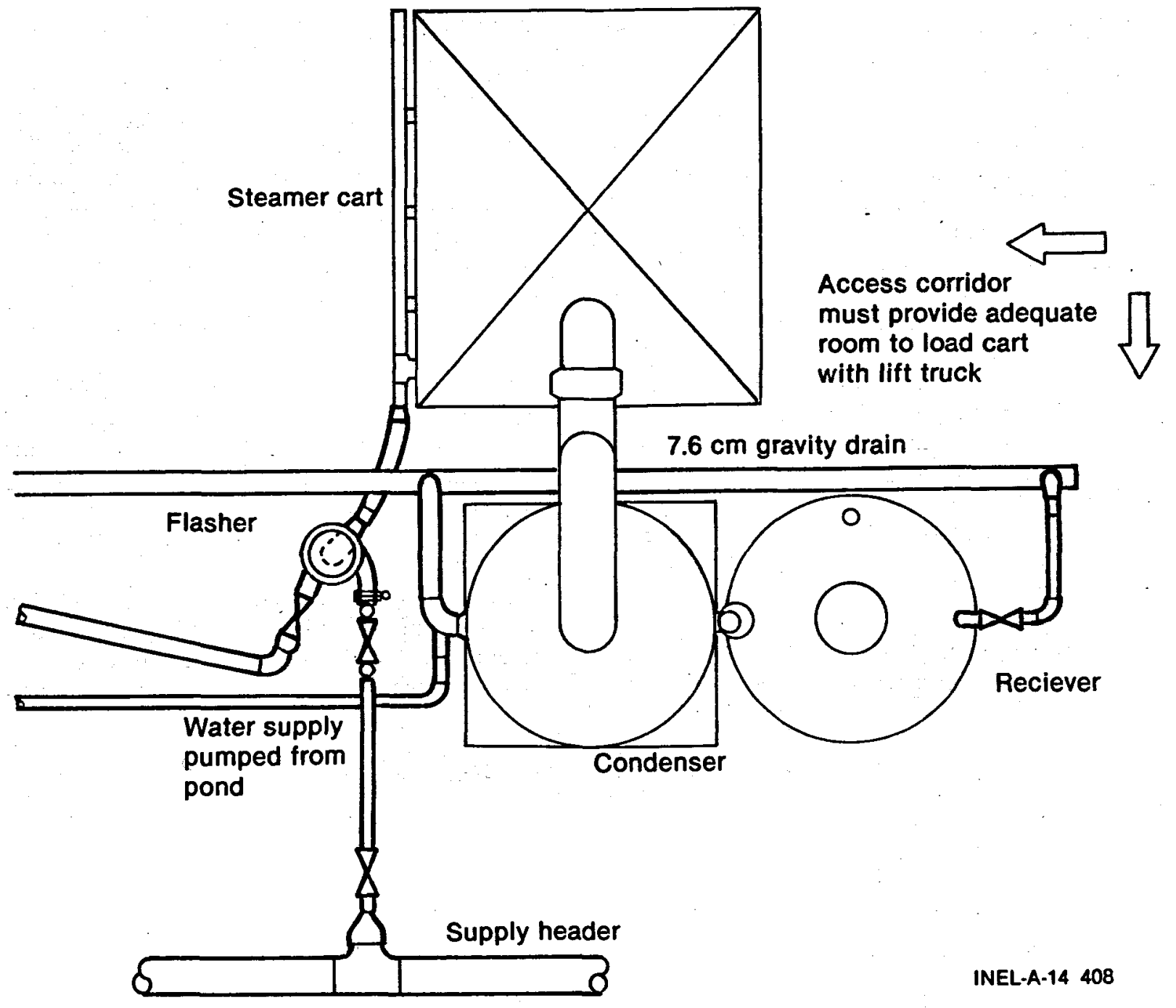

Figure 12. Schematic of extraction equipment showing the scale and placement of component items.

of time by storing in a cold storage warehouse at $-17.8^{\circ} \mathrm{C}$. The harvested crop was collected during the early hours because dew would help to maintain the moisture content of the cut plants. The crop was then placed into plastic bags (liners) inside $0.85-\mathrm{m}^{3}$ corrugated cardboard potato tote bins. Sixteen such containers were placed in cold storage and withdrawn at the rate of 2 to 3 per experimental run. The total experiment run covered more than 2-1/2 months. The peppermint crop, thus stored, crystallized, and a thawing time of 2 to 3 hours was needed before the crop was placed in the steamer cart for distillation. Between 1.7 and $2.5 \mathrm{~m}^{3}$ of material ( 2 to 3 boxes) was then subjected to live geothermal steam produced by flashing 112.8 to $133.3^{\circ} \mathrm{C}$ water to the desired 7030 to $11952-\mathrm{kg} / \mathrm{m}^{2}$ steam pressure. The geothermal steam was monitored by observation through a discharge pipe vented outdoors prior to connection to the steamer cart. When sufficient quality steam (dry) of the correct pressure was obtained, the steamer cart was connected, and the steam distillation process commenced. Figure 13 shows a photo of the combined components. Process water was taken from two different wells; water chemistry of these wells is shown in Table 3. The processes involved thereafter were identical to conventional activities and involved the following steps.

1. Steaming the Plant Material. A breakthrough time is required to steam the material, which increases its temperature and breaks open the cellular structure to release the oil. A simmering period follows, at which time sufficient steam 


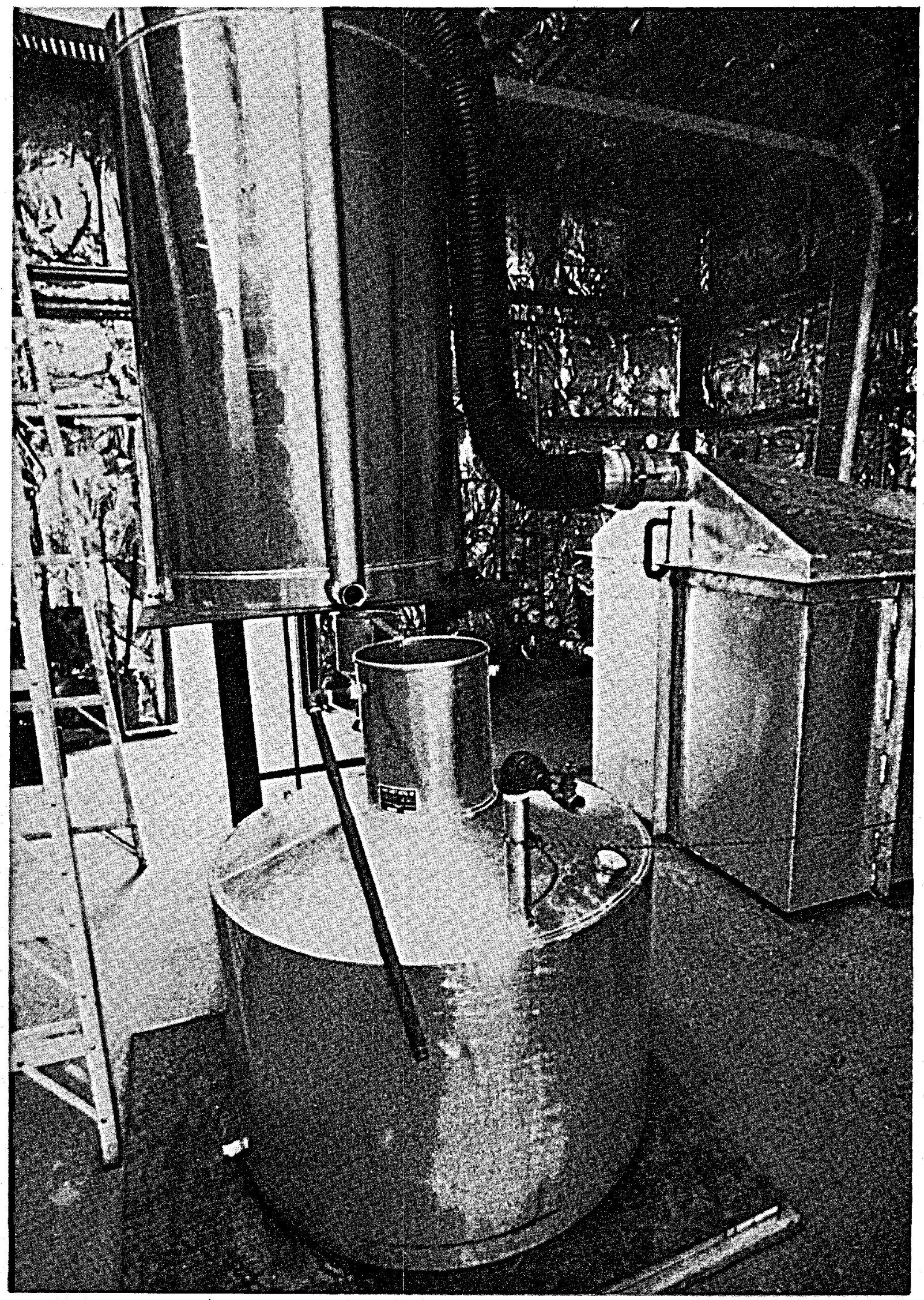

Figure 13. Photo of geothermal extraction equipment. 


\begin{tabular}{|c|c|c|c|c|c|c|}
\hline $\begin{array}{l}\text { Well } \\
\text { Number }\end{array}$ & $\begin{array}{c}\text { Conductivity } \\
(\mu \mathrm{mhos} / \mathrm{cm})\end{array}$ & $\begin{array}{l}\mathrm{Cl}^{-} \\
\text {(ppm) }\end{array}$ & $\begin{array}{c}F^{-} \\
\text {(ppm) }\end{array}$ & $\begin{array}{l}\mathrm{Ca} \\
\text { (ppm) } \\
\end{array}$ & $\mathrm{pH}$ & $\begin{array}{c}\text { Carbonate } \\
\text { Hardness } \\
\text { (ppm) }\end{array}$ \\
\hline $2^{a}$ & 5200 & 1000 & 7.65 & 68 & - & -- \\
\hline $2^{b}$ & 3025 & 880 & 6.84 & 51 & 7.4 & 40.4 \\
\hline $2^{C}$ & 2450 & 670 & 9.17 & -- & 8.1 & 82.0 \\
\hline $2^{d}$ & 2590 & 650 & 8.79 & 39 & 6.1 & 74.0 \\
\hline $1 \mathrm{e}$ & 2860 & 850 & 7.43 & 52 & 8.0 & 78.8 \\
\hline \multicolumn{7}{|c|}{ Sample taken September $18,1979}$. \\
\hline \multicolumn{7}{|c|}{ b. Sample taken October 18,1979} \\
\hline \multicolumn{7}{|c|}{ c. Sample taken October $23,1979}$. \\
\hline \multicolumn{7}{|c|}{ d. Sample taken October 29, 1979.} \\
\hline e. So & taken Novembe & 1979 & & & & \\
\hline
\end{tabular}

temperature and pressure (normally lower than that required to break through) is used to maintain the oil extraction process.

2. Condensing the Steam and Oil Vapor. The steam and oil vapor from the steamer cart are at essentially atmospheric pressure and rise into the top of the condenser unit. The condenser was a shell and tube design with condensing flow on the shell side. A vent tube provided protection against pressure buildup.

3. Receiver Process. The condensed steam and oil vapor flow out of the bottom of the condenser into a receiver vessel. The insolubility of the mint oil separates the oil from the water, and the density difference allows the oil to flow and be collected on top of the water level. The temperature of water in the receiver vessel is maintained at a temperature level best suited to maximize separation of oil and water.

\section{Experiment Results}

The main objective of the experiment was to determine any quality and flavor variations from geothermal steam use versus use of fossil fuel generated steam. However, other parameters were monitored and controlled to ascertain maximum operational characteristics. Table 4 summarizes the operational parameters for the 8 total trial runs. The main parameters monitored were steam pressure, condenser flow and temperature, and geothermal water flow. Early trials consisted of using well number 2 (RRGP-2) whose lower temperature (less than $123.3^{\circ} \mathrm{C}$ ) failed to flash sufficient quantities of steam to extract the peppermint oil. Large quantities of condensed steam remained in the steamer cart in these early trials. Modifications to the flasher vessel could have 
TABLE 4. EXTRACTION PROCESS OPERATIONAL PARAMETERS

\begin{tabular}{|c|c|c|c|c|c|c|c|c|c|}
\hline $\begin{array}{c}\text { Number } \\
\text { of } \\
\text { Boxes }\end{array}$ & $\begin{array}{l}\text { Trial No.l } \\
\text { Well No. } \\
\end{array}$ & $\begin{array}{l}\text { Temperature } \\
\left.\quad{ }^{\circ} \mathrm{C}\right) \\
\end{array}$ & $\begin{array}{c}\text { Flow } \\
\left(\mathrm{m}^{3} / \mathrm{hr}\right)\end{array}$ & $\begin{array}{r}\text { Steam } \\
\left(\mathrm{kg} / \mathrm{m}^{2}\right)\end{array}$ & $\begin{array}{c}\text { Cooling } \\
\text { Water } \\
\text { Inlet } \\
\text { Temperature } \\
\left({ }^{\circ} \mathrm{C}\right) \\
\end{array}$ & $\begin{array}{l}\text { Cooling } \\
\text { Water } \\
\text { outlet } \\
\text { Temperature } \\
\left({ }^{0} \mathrm{C}\right)\end{array}$ & $\begin{array}{l}\text { Cooling } \\
\text { Water } \\
\left(\mathrm{m}^{3} / \mathrm{hr}\right)\end{array}$ & $\begin{array}{c}\text { Output } \\
\text { (g) }\end{array}$ & Remarks \\
\hline 2 & $1 / 1$ & 118.3 & 1.8 & -- & 31.1 & 33.3 & 4.1 & 283.5 & - \\
\hline 2 & $2 / 1$ & 123.3 & 1.5 & 10124.2 & 24.4 & 27.2 & 7.0 & 283.5 & $\begin{array}{l}\text { Condensed } \\
\text { water left } \\
\text { in vat. }\end{array}$ \\
\hline 2 & $3 / 2$ & 122.2 & 1.9 & 12303.3 & 22.2 & 24.4 & 7.0 & 946.4 & -- \\
\hline 2 & $4 / 2$ & 121.1 & 1.6 & 10546.1 & 15.6 & - & $7: 0$ & -- & -- \\
\hline 3 & $5 / 1$ & 132.2 & 1.6 & 11248.1 & 21.1 & - & $7: 0$ & 2839.1 & - \\
\hline 3 & $6 / 1$ & 132.2 & 1.6 & 11248.1 & 15.6 & - & 7.0 & 3785 & -- \\
\hline 2 & $7 / 1$ & -- & -- & -- & -2 & - & 7.0 & - & - \\
\hline (2 bushels) & $8 / 1$ & 133.3 & 1.7 & 11248.1 & 16.7 & 23.3 & 6.6 & None & $\begin{array}{l}\text { Water left } \\
\text { in vat. } \\
\text { Material } \\
\text { contained } \\
\text { almost no } \\
\text { seeds. }\end{array}$ \\
\hline
\end{tabular}


alleviated these problems. Theoretical calculations predicted temperatures as low as $112.8^{\circ} \mathrm{C}$ as being acceptable to produce the needed $10.546 \mathrm{~kg} / \mathrm{m}^{2}$ steam. Higher condensing water temperatures (nearly $31.1^{\circ} \mathrm{C}$ in trial 1) were also thought to contribute to low production output, however this was not confirmed in later tests.

Subsequent tests were performed using hotter water from well number 1 (RRGP-1) of nearly $132.2^{\circ} \mathrm{C}$. Successful extraction of mint oil was accomplished in all subsequent trial runs using this higher temperature water. The color of the produced oil seemed clearer and cleaner than earlier oil samples which were thought to be slightly offcolor due to the freezing of the plant material. However, these latter tests tended to prove no adverse effects were caused by the freezing and subsequent discoloration. The oil samples produced by trial run number 1 have been analyzed and compared favorably to a control sample. The control sample was taken from the same field and processed by the grower using similar equipment, but using steam generated by fossil fuel. The control sample was processed under normal scheduling, and was not frozen or in any way variable from what would be considered standard conditions. See Table $\mathbf{S}$ for an oil analysis.

Dill oil was also processed. Dill from a local source was donated for experimentation. The plant material had experienced deep frost conditions because it was harvested in early November, 1979, nearly two months later than normal. Therefore, the operation of the essential oil equipment produced insufficient dill oil for analysis.

In conclusion, the prime objective had been confirmed. No adverse effect on quality or flavor of peppermint oil using geothermal water was observed. Results of other trial runs are still pending, however these subsequent clearer samples should be of better quality and flavor than the samples of the first trial.

\section{AIR CONDITIONING EXPERIMENTS}

Air conditioning using moderate temperature geothermal fluids as the energy source is being evaluated as part of the overall space conditioning evaluations being performed within EG\&G's geothermal direct applications program. The 1979 test program centered on data acquisition from a lithium bromide absorption unit installed in an operations building on site. The data from this unit are presented below.

Successful operation of air conditioning systems with source temperatures down to $82.2^{\circ} \mathrm{C}$ was the principal finding of these experiments. Performance curves were derived to show effeciency as a function of source temperature. In addition, at the end of the year, plans were finalized for testing an innovative system that could function efficiently on source temperatures as low as $40.6^{\circ} \mathrm{C}$.

\section{Background}

Air conditioning uses nearly $4 \%$ of the total U.S. yearly energy consumption. The majority of the air conditioning requirements are satisified by high efficiency electric drive air conditioners; however the inefficient generation of electricity consumes large amounts of fossil fuels. Geothermal energy could be the energy source used to provide power for air conditioning systems through either existing equipment or through the development of equipment more suitably matched to this energy source. The existing equipment includes:

- Water-to-air or water-to-water heat pumps

- Absorption air conditioners

- Centrifugal units mechanically driven by geothermal water.

Currently, water sourced heat pumps operate with input water temperatures between 15.6 and $32.3^{\circ} \mathrm{C}$. Equipment operating with lower source temperatures is now coming on line and is expected to help satisfy air conditioning and heating requirements with ground water temperatures or higher.

Present absorption-type air conditioners are either of the lithium bromide-water or the ammonia-water absorption units. Both use water as the refrigerant. Geothermal water could be used as the driving energy source at the generator to liberate water vapor from the lithium bromide or ammonia solution. The water vapor is utilized in a comparable equipment fashion through the condensing and evaporating stages. Water 
TABLE 5. OIL ANALYSIS--SAMPLE

\begin{tabular}{|c|c|c|c|c|c|c|c|c|c|}
\hline Sample & & Type & Grade & $\begin{array}{l}\text { Lighter } \\
\text { Boiling } \\
\text { Turpines } \\
\quad(\%) \\
\end{array}$ & $\begin{array}{c}\text { Menthofuran } \\
(\%)\end{array}$ & $\begin{array}{l}\text { Alcohol } \\
\text { Menthal, } \\
(\%) \\
\end{array}$ & $\begin{array}{l}\text { Ketone } \\
(\%)\end{array}$ & $\begin{array}{c}\text { Ester } \\
(\%)\end{array}$ & Contamination \\
\hline Geothermal & I daho & Peppermint & $02^{\mathrm{a}}$ & 13.8 & 1.0 & 57.3 & 19.9 & 6.6 & $\begin{array}{l}\text { Estimated } \\
\text { Weight }\end{array}$ \\
\hline Geothermal & Idaho & Peppermint & 02 & 10.4 & 1.1 & 61.9 & 17.7 & 6.6 & $\begin{array}{l}\text { Estimated } \\
\text { Weight }\end{array}$ \\
\hline Geothermal & Idaho & Peppermint & 02 & 10.9 & 0.9 & 61.7 & 18.0 & 6.5 & $\begin{array}{l}\text { Estimated } \\
\text { Weight }\end{array}$ \\
\hline \multirow[t]{2}{*}{ Geothermal } & \multirow[t]{2}{*}{ Idaho } & \multirow[t]{2}{*}{ Peppermint } & $01^{b}$ & 11.8 & 1.5 & 59.6 & 18.6 & 6,6 & $\begin{array}{l}\text { Estimated } \\
\text { Weight }\end{array}$ \\
\hline & & & Average & 11.0 & 1.1 & 61.0 & 18.1 & 6.5 & $\begin{array}{l}\text { Estimated } \\
\text { Weight }\end{array}$ \\
\hline Control & Idaho & Peppermint & $03^{C}$ & 12.6 & 4.6 & 51.6 & 21.9 & 5.5 & $\begin{array}{l}\text { Est imated } \\
\text { Weight }\end{array}$ \\
\hline $\begin{array}{l}\text { a. Grade } 0 \\
\text { b. Grade } 0\end{array}$ & \multirow{2}{*}{\multicolumn{3}{|c|}{$\begin{array}{l}\text { denotes slightly off prime- } \\
\text { denotes prime Idaho type. } \\
\text { denotes menthofuran above } 4\end{array}$}} & cause unk & wn, but enti & ely accept & & & \\
\hline c. Grade 0 & & & & this $\mathrm{p}$ & cular cont & group & lot $h$ & en $t$ & ical. \\
\hline
\end{tabular}


temperature requirements for current off-the-shelf equipment is 71.1 to $148.9^{\circ} \mathrm{C}$, with higher operating efficiences at the higher temperatures. Newer generation equipment may lower these temperatures somewhat.

There is a water temperature gap, therefore, between 32.2 and $71.1^{\circ} \mathrm{C}$ that cannot be used for air conditioning equipment, at least with current technology. Heat pumps can be custom designed to operate at higher water temperatures than $32.2^{\circ} \mathrm{C}$, however, by substituting an air coil (thus becoming an air sourced unit) which is more economical and practical. Some research work is being performed by private companies to lower the temperatures required by absorption systems. The improvement of efficiencies while operating at these lower temperatures is also being researched.

Research and development work at the Idaho National Engineering Laboratory's Geothermal Test Site is centered on using moderate temperature $\left(\mathrm{K} 100^{\circ} \mathrm{C}\right)$ geothermal resources to provide air conditioning. The more common geothermal sources are below $100^{\circ} \mathrm{C}$, and exponentially increase in number as the temperature decreases. Furthermore, lower temperature geothermal resources can normally be found at shallower depths, thereby becoming the cheaper resources to exploit. Efficiency, in terms of standard heating, venting, and air conditioning (HVAC) terms, for air conditioners is rated by the coefficient of performance (COP). Simply stated, the COP is a ratio of energy out (cold air or water) divided by energy in (electric energy). The geothermal, solar, or waste water heat as a required input is not included in the overall efficiency for COP. Therefore, higher efficiency air conditioners in terms of COP require increasingly higher amounts of water energy relative to electric energy. If the source of water is not free, the operational costs of the air conditioner increase. Again, shallower aquifer and lower temperature geothermal resources are the most practical and economical.

The approach taken for this air conditioner experiment is to examine low-temperature sourced equipment. A survey of manufacturers was conducted to identify manufacturers of residential sized space cooling systems which would operate on low-temperature geothermal water. A lithium bromide absorption air conditioner was purchased from Arkla Industries Inc. This became a control unit for latter comparison with other equipment. The second part of the experiment will be conducted early in 1980 and will examine a prototype low-temperature, water sourced, diaphragm-type air conditioner that operates with water temperatures as low as $40.6^{\circ} \mathrm{C}$. This unit has been built by a private concern and will be examined for operational characteristics and performance with geothermal water. The test conducted during 1979 therefore, consisted of evaluation of the control lithium bromide unit.

\section{Test Setup}

The experimentation of the Arkla Industries Inc. unit consisted of (a) installation and checkout, (b) obtaining operational characteristics as a function of input parameters such as source temperatures and pressures, and (c) data collection for eventual comparison with air conditioner units. The model purchased was a model 501-WF Solaire and was tested under factory rated conditions. The operational requirements included:
A. Hot water $=$
82.2 to $98.9^{\circ} \mathrm{C}$
supply
temperature
Flow rate
Pressure drop $=10.3 \mathrm{~cm} \mathrm{Hg}$

The water was supplied from a closed secondary loop heated by geothermal water through a tube and shell heat exchanger.
B. Cooling water $=21.1$ to $29.4^{\circ} \mathrm{C}$ supply temperature Flow rate $\quad=\quad 2.27 \mathrm{~m}^{3} / \mathrm{hr}$ Pressure drop $=8.96 \mathrm{~cm} \mathrm{Hg}$
C. Electric $=115 \mathrm{~V}, 8.0 \mathrm{amp}$ requirements with a typical wattage draw of $450 \mathrm{~W}$.
D. Cooling air $=1699$ to 2378.6 flow $\mathrm{m}^{3} / \mathrm{hr}$

\section{System Operation}

The entire unit operates under a vacuum at all times. The absolute pressure within the system will 
vary depending upon operating conditions. The absolute pressure within the generator and condenser is in the order of 30 to $60 \mathrm{~mm}$ of mercury absolute, and the pressure within the cooling coil and absorber is 6 to $9 \mathrm{~mm}$ of mercury absolute.

Figure 14 shows the solution flow diagram of the lithium bromide and distilled water; the water being the refrigerant, and the lithium bromide solution being the absorbent.

Referring to the figure, the generator (1) contains a solution of lithium bromide in water. When sufficient heat is applied to the coil (20) in the generator, it causes the refrigerant (water) to be boiled off. As this water vapor is driven off, the absorbent solution is raised by vapor lift action through tube (2) into the separating chamber (3).

Here the refrigerant vapor and the absorbent solution are separated by baffles. The refrigerant vapor rises through tube (4) to the condenser, and the absorbent solution flows down by gravity through tube (6), through the heat exchanger and then to the absorber. This circuit will be described in more detail with the refrigerant circuit being decribed first.

The refrigerant (water vapor) passes from the separating chamber to the condenser through tube (4), where it is condensed to a liquid by the action of cooling water flowing through the condenser tubes. The cooling water is brought from an external source, such as a cooling tower, city main, or well.

The refrigerant vapor thus condensed to water within the condenser then flows through tube (5) into the cooling coil. Tube (5) contains a restriction which offers resistance and therefore a pressure barrier to separate the slighty higher absolute pressure in the condenser from the lower pressure within the cooling coil. The refrigerant (water) entering the cooling coil vaporizes due to the lower absolute pressure (high vacuum) which exists within it. The high vacuum within the evaporator lowers the boiling temperature of the water sufficiently to produce the refrigeration effect.

The evaporator or cooling coil is constructed with finned horizontal tubes, and the air being cooled flows over the coil surface. Evaporation of the refrigerant takes place within the cooling coil. The heat of evaporation for the refrigerant is extracted from the air stream, and cooling and dehumidifying are thus accomplished.

In the absorber, the solution absorbs the refrigerant vapors which are formed in the evaporator directly adjacent.

To explain the presence of the absorbent at this point it is necessary to divert attention back to the generator. The absorbent was separated from the refrigerant by boiling action. The absorbent then drains from the separator (3) down to the liquid heat exchanger and then to the absorber through tube (8). The flow of solution in this circuit actually exists by gravity action alone, because the absorber is slightly below the level of the separating chamber. It is also aided by the pressure difference existing between the separator and the absorber.

The absorber is a cylindrical shell which contains a coil through which cool water is circulated. The solution flowing into the top of the absorber is distributed over the entire outside surfaces of the coil so that a maximum area of absorbent solution is exposed to the refrigerant vapor which is flowing into this chamber from the evaporator.

It must be understood at this point that cool lithium bromide in either dry or solution form has a very strong affinity for water vapor. It is because of this principle that the refrigerant vapor is absorbed back into solution again. The rate of absorption is increased at lower temperatures, therefore a cooling water coil has been provided within the absorber shell. The resultant mixture of refrigerant and absorbent drains back through the heat exchanger through tube (9), to the refrigeration generator where it is again separated into its two component parts by boiling action, to repeat the cycle.

Because of the slightly higher absolute pressure in the separator, as compared to the cooling coil or evaporator, absorbent solution rises through tube (17) and through the liquid trap (7) and up into tube (16), thereby forming a liquid seal so that refrigerant vapor cannot flow through tube (15) from the separator chamber. The cooling cycle is maintained in this manner. 


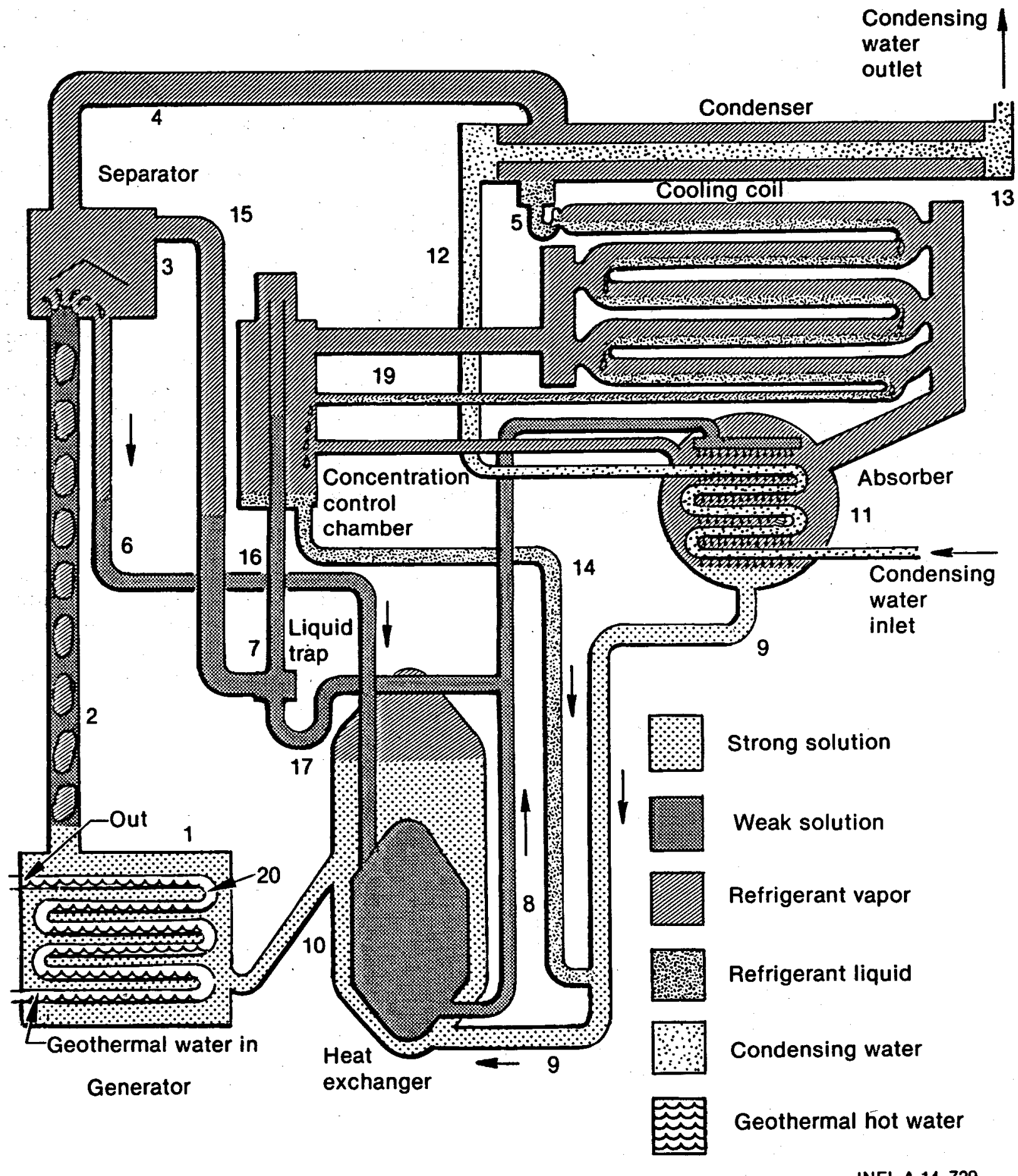

INEL-A-14 729

Figure 14. Solütion fiow diagram of the lithium bromide and distilled water for an absorption air conditioning system. 


\section{System Performance}

The lithium bromide air conditioner was installed in a building whose size was similar to a typical residence. Building size was $8.5 \times 21.9 \mathrm{~m}$ thus having approximately $187.2 \mathrm{~m}^{2}$. Geothermal water heated a secondary water flow to avoid any possible corrosion effects. The addition of hot water coils in the delivery ducts allowed the use of geothermal water to provide both heating and cooling. The unit performed as per manufacturers specifications. The air flow was adjusted to $2002.8 \mathrm{~m}^{3} / \mathrm{hr}$; and output performance was measured by monitoring air temperature variations before and after the cold deck. Flow meters monitored the hot water and condensing water flows. These meters were of an automatic control type set at $2.73 \mathrm{~m}^{3} / \mathrm{hr}$ : for hot water and $2.27 \mathrm{~m}^{3} / \mathrm{hr}$ for condensing water flows. Each of these valves has a bypass valve for experimental testing.

An automatic valve prevents hot water flow if the supply temperature is lower than $87.8^{\circ} \mathrm{C}$. A mixing valve prevents cooling water supply temperatures lower than $23.9^{\circ} \mathrm{C}$, as recommended by the manufacturer.

Dial thermometers measured hot water and condensing water temperatures at the inlets and outlets. Pressure gauges measured inlet and outlet pressure for the two water circuits.

The air distribution system provides for two zones of heating and cooling. The conference room is one zone, and the control room is the other zone. A priority switch located next to the air conditioning unit allows either zone to be selected as having priority over heating or cooling. The "off" position on the switch allows heating or cooling to both zones as required. Changeover from heating to cooling is done manually by a selector switch.

Figures 15 and 16 illustrate the design ducting and piping schematics.

Under typical operating conditions, the unit provides $10545 \mathrm{~W}$ cooling when provided with approximately $16764 \mathrm{~W}$ hot water input $(C O P=65 \%)$. Heat rejection was nearly $27736 \mathrm{~W}$ and was accomplished by a cooling tower. Typical electrical draw for circulating fan and control circuits is $450 \mathrm{~W}$. No solution pumps are utilized in this model.

Figure 17 indicates the output cooling capacity as a function of generator inlet temperatures when operating with $26.7^{\circ} \mathrm{C}$ condensing water. Care needed to be exercised at the lower temperature limits to avoid under firing conditions. The coefficient of performance can be measured in terms of output capacity and is also shown in Figure 17.

In conclusion, the lithium bromide unit is still undergoing data collection and will be reported on in greater detail at a later date. The unit has operated as predicted and fulfills air conditioning requirements with geothermal water temperatures of $82.2^{\circ} \mathrm{C}$ or higher. Results of these tests will be compared to an advanced diaphragm-type air conditioner which will undergo performance testing in early 1980. 


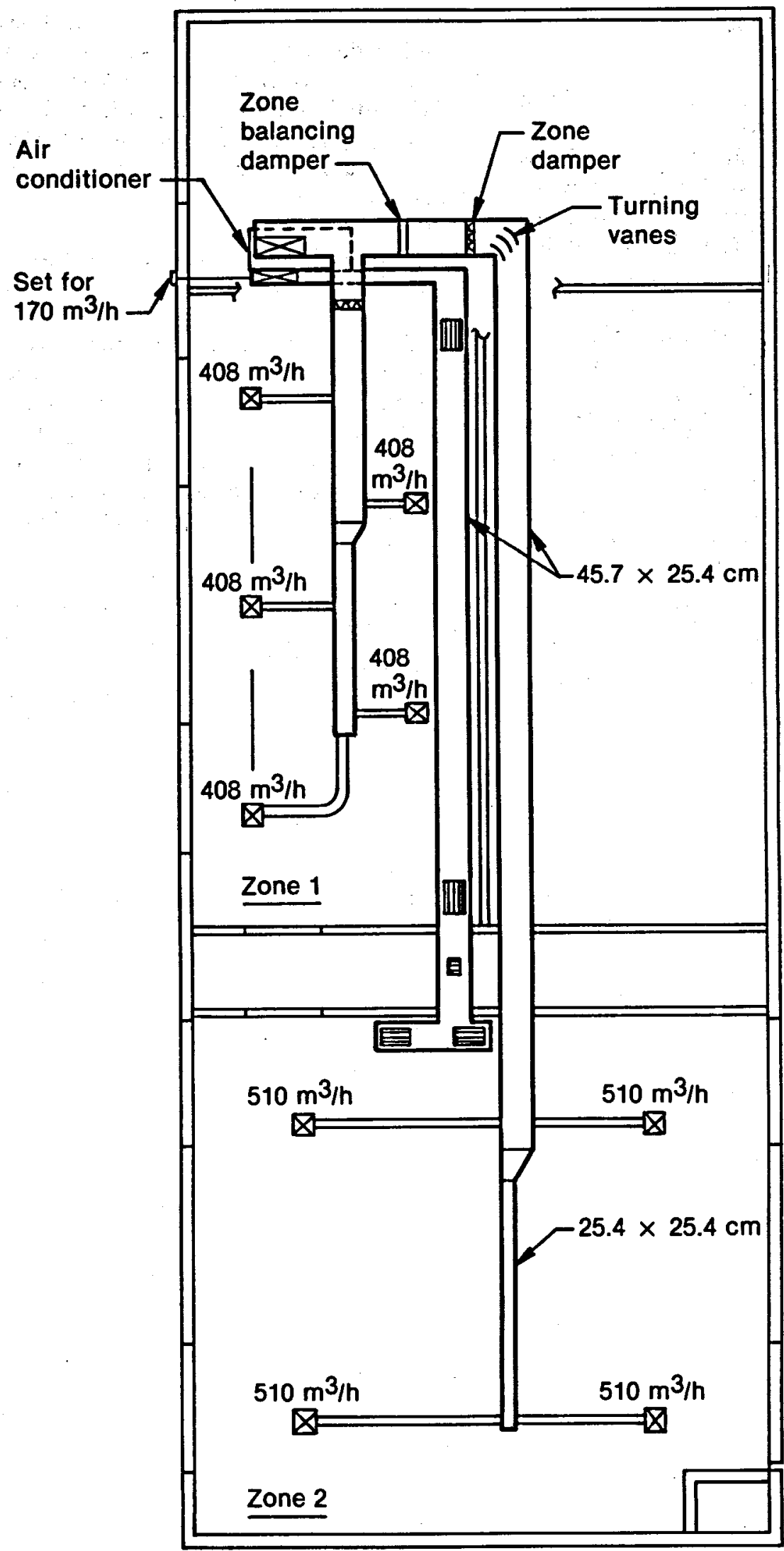

INEL-A-14 418

Figure 15. Design ducting schematic for air conditioner. 


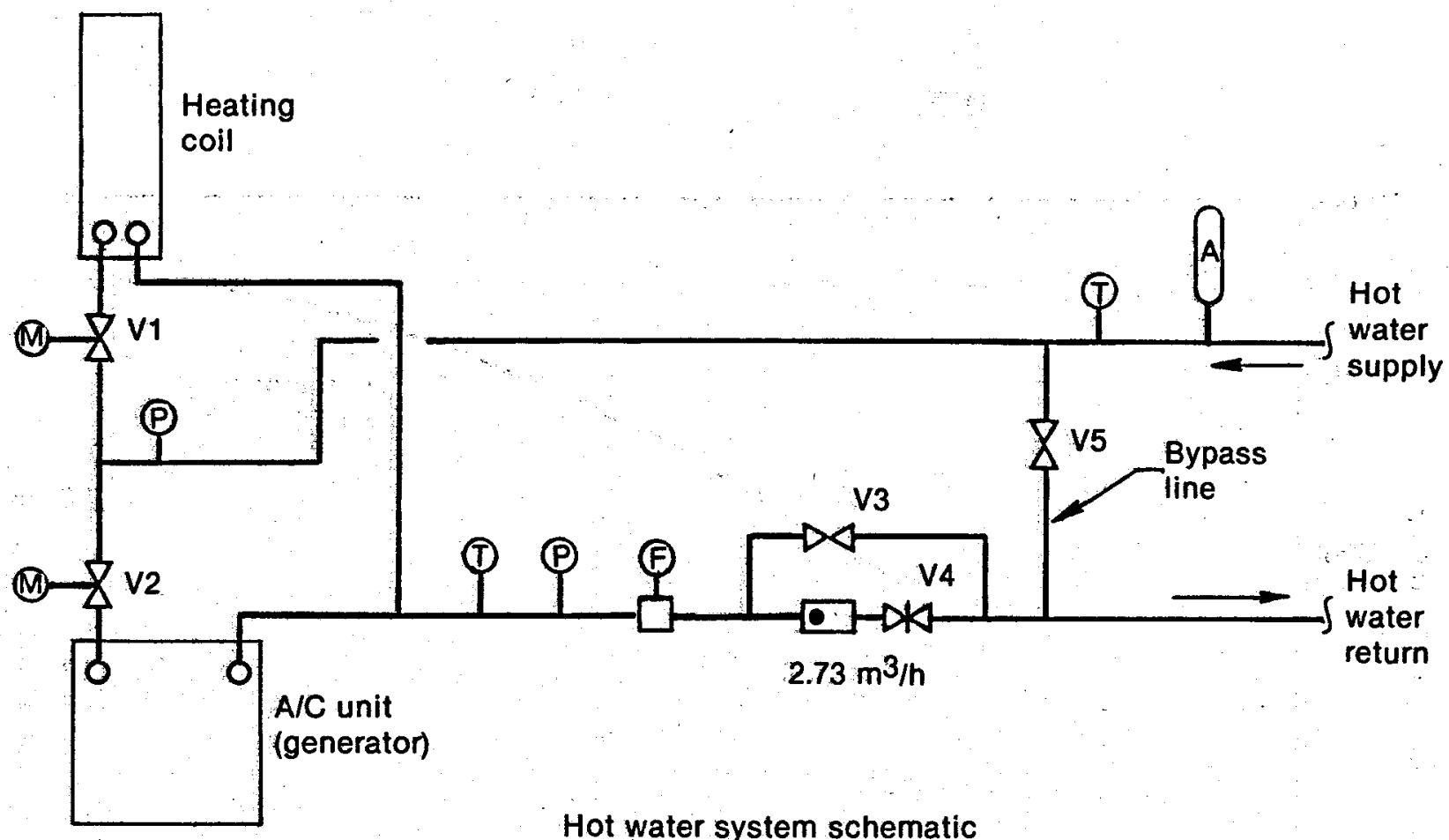

Hot water system schematic

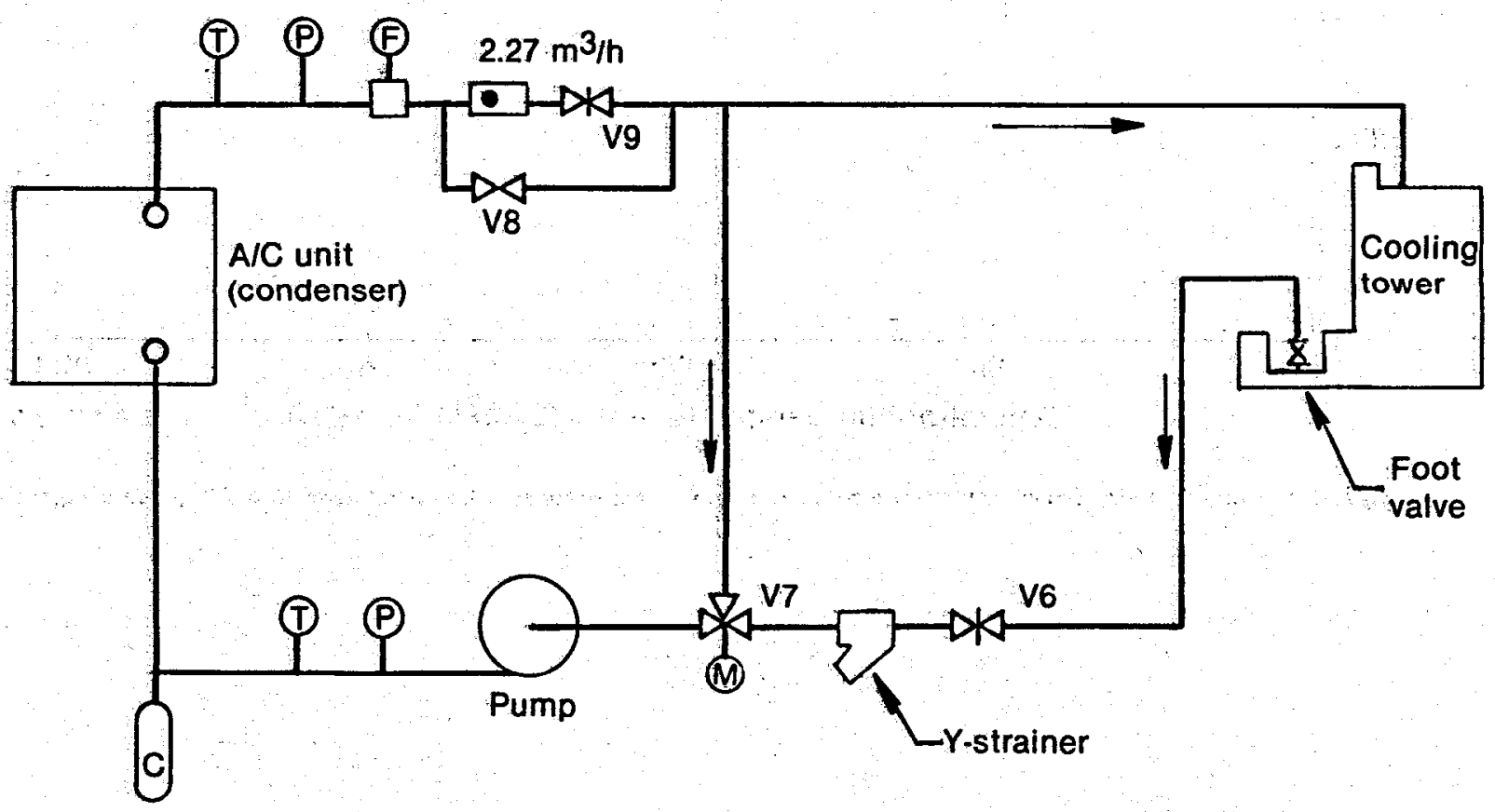

Cooling water system schematic

INEL-A-14 412

Figure 16. Design piping schematic for air conditioner. 


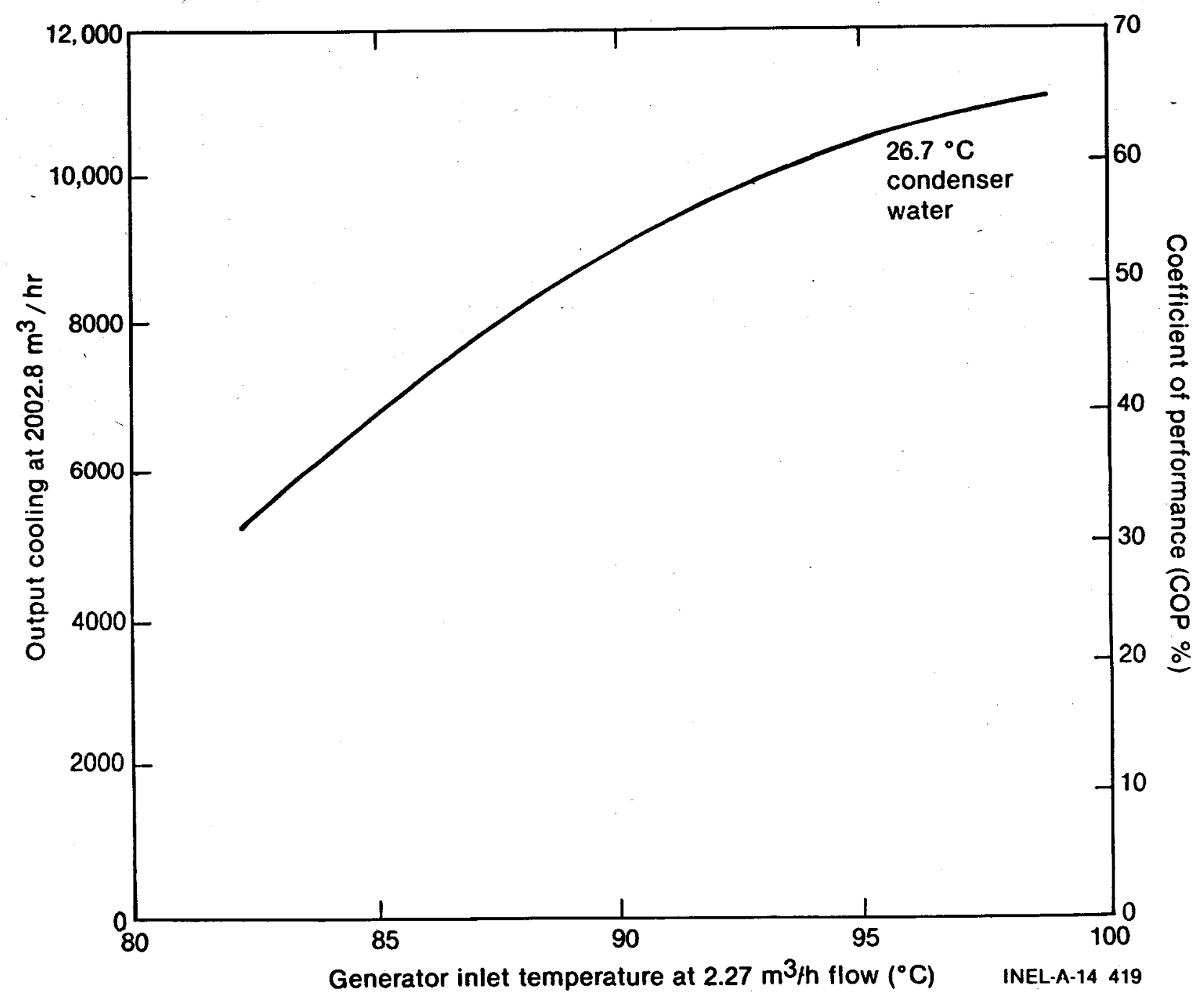

Figure 17. Output cooling capacity as a function of generator inlet temperatures when operating with $26.7^{\circ} \mathrm{C}$ condensing water. 


\section{SMALL-SCALE ALCOHOL DEMONSTRATION}

About mid-summer 1979, DOE and EG\&G Idaho resolved to build a small-scale biomass-toalcohol conversion unit at the Raft River Geothermal Site to answer some of the uncertainties surrounding state-of-the-art geothermal assisted biomass conversion. The unit was successfully operated by the end of August producing a quantity of $95 \%$ ( 190 proof) ethanol.

\section{Background}

The near-term possibility of blending biomassderived alcohol (ethanol) with gasoline for transportation fuels is receiving considerable attention. There are compelling reasons for carefully considering alcohols produced from biomass as potential fuels:

1. Biomass fuels are renewable and thereby reduce our nation's dependence on nonrenewable petroleum resources

2. Biomass resources such as wheat, corn, grain, sugar cane, sugar beets, and potatoes are readily available and can benefit from increased market potential

3. Alcohol blended with gasoline is a successful motor fuel with blends of 5 to $15 \%$ in current generation automobiles.

The national need for liquid fuels, current interest in gasohol, and the closure of a number of western sugar plants suggests an initial potential for alcohol production from sugar beets. There is substantial support from legislative representatives for DOE to direct a part of its INEL geothermal effort to liquid fuel conversion possibilities. Using geothermal heat to produce alcohol can be viewed as a technology to convert geothermal energy to a transportable energy supply. The use of geothermal energy to produce alcohol does not require the inefficient expenditure of fossil energy and may significantly improve conversion economics. Sugar beet production accounts for $\mathbf{4 5}$ to $50 \%$ of all raw sugar produced. Sugar beets are a tough and adaptable plant, grown to a large extent in the intermountain, mountain, and semitropic Californian Imperial Valley. The closure of many western pro- cessing plants has created a serious problem because the sugar beet is a valued rotation crop in much of the intermountain west. Production of alcohol from various other feedstocks would provide consistent supply and greater long-term merit than alcohol production from sugar beets.

\section{System Approach and Description}

The small-scale geothermal/biomass pilot unit to ethanol demonstrates the application of geothermal fluids to chemical processing plants. In this unit, sugar beet derived beer (8 to $10 \%$ alcohol) is distilled to produce $95 \%$ ethanol. The beer is preheated with the still bottoms to near its vapor saturation point prior to entering the still. The energy to the reboiler is provided by geothermal fluid through a shell-and-tube heat exchanger. In the reboiler, the still bottoms are partially vaporized and then pass up through the distillation column contacting the down flowing liquids. The column itself is constructed of two sections. The bottom or rectifying section of the column contains $121.9 \mathrm{~cm}$ of ceramic saddle packing. The top or stripping section contains stainless steel pall rings and is $304.8 \mathrm{~cm}$ in height. The feed is introduced between the rectifying and stripping sections of the still. The vapors leaving the top of the still are condensed in the closed loop condenser. Approximately $90 \%$ of the condensed liquids are returned to the still as reflux; the remaining $10 \%$ is taken off as a $95 \%$ ethanol $15 \%$ water product. Because the ethanol/water system forms a constant boiling azeotrope ( $96 \%$ ethanol), a still cannot produce $100 \%$ ethanol at atmospheric conditions. In a production plant, anhydrous alcohol would be produced by mixing the $95 \%$ ethanol $/ 5 \%$ water solution with an azeotrope breaker, e.g. benzene, and then passsed through additional distillation equipment. The temperature regime required for this azeotrope breaking step is also compatible to those of geothermal fluids, and would also utilize geothermal heat.

The block diagram in Figure 18 shows the different steps in the production of pure $(\mathbf{9 9 . 9 \%})$ alcohol. The Geothermal Alcohol Production Plant (GAPP) was completed in two phases. Referring to Figure 18, the first phase consists of the fermentation tank and the first distillation column. The second phase, still in the planning stage, will consist of the second distillation column and the solvent recovery column. 
Feed stock

(12 to $16 \%$ sugar)

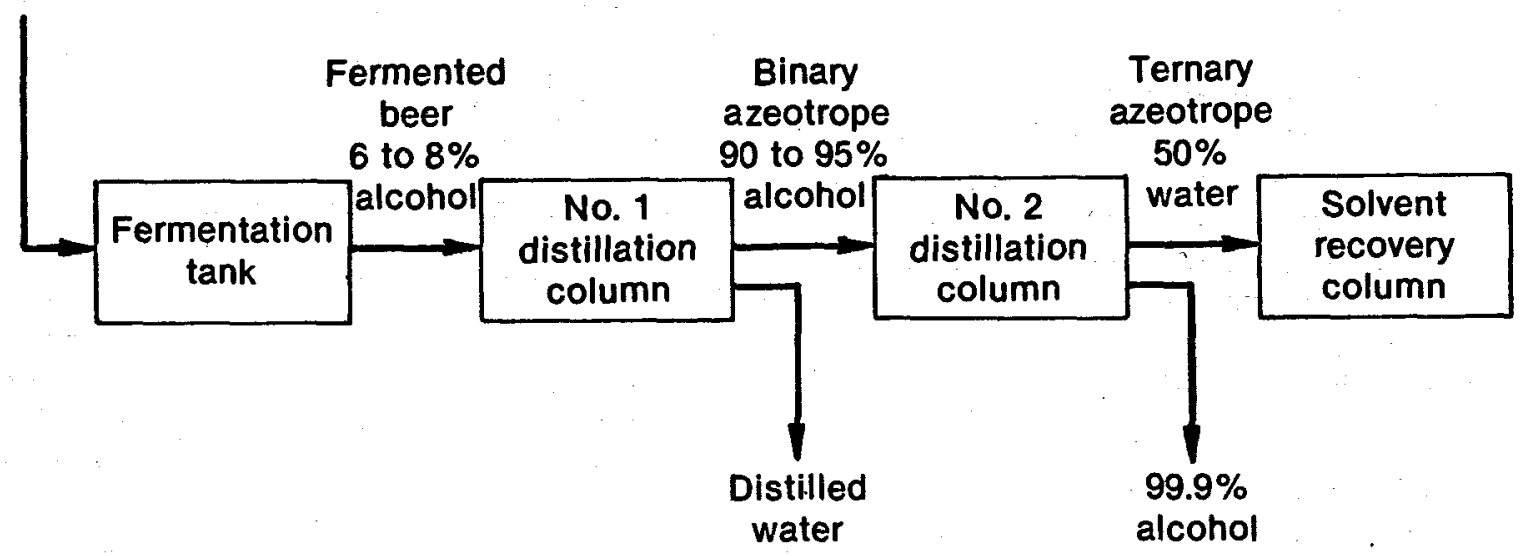

INEL-A-14 732

Figure 18. Block diagram showing the different steps in the production of pure $(99.9 \%)$ alcohol.

Operation of the first phase produced 90 to $95 \%$ alcohol. A more detailed flow diagram and a layout of the first phase are shown in Figure 19. The second phase equipment will use the $90 \%$ alcohol produced from the first phase to produce 99.9\% alcohol.

The GAPP flow paths are shown in Figure 19. Starting at the feed pump, which takes suction from the fermentation tank, the fermented beer is pumped through the shell side of the coiled tube preheater. This preheats the beer to a temperature near the saturation point. The preheated beer is directed to the distillation column. The distillation column is made of two sets of packing material. The beer enters the column between these two sections. The top section or striping section packing is $3.05 \mathrm{~m}$ of stainless steel pall rings. The bottom or rectifying section packing is $\mathbf{1 . 2 2} \mathrm{m}$ of ceramic saddles.

The alcohol content within the column varies from near zero at the bottom to $90 \%$ at the top. The $90 \%$ alcohol vapor at the top is directed to the shell side of a coiled tube condenser, where it is condensed and cooled. The reflux pump takes suction from the condenser and returns $90 \%$ of the cooled alcohol to the column. This is called reflux. The cold water for condensing the alcohol is cir- culated through the coiled tubes by the cooling water pump through a fan radiator-type water cooler.

Control of the GAPP is accomplished strictly by manual control. A system is being installed which will provide semiautomatic control. This system will control the level in the reboiler by adjusting the flow of boiler bottoms. The reflux flow will be controlled by the level in the condenser. Geothermal fluid flow will be controlled by measuring the temperature at one point in the rectifying geothermal flow to give the proper vaporization rate and temperature in the column.

At the bottom of the distillation column, the boiler pump pumps the bottoms (primarily water) to the boiler and preheater. Approximately $\mathbf{8 0 \%}$ of the bottoms are directed to the preheater to heat the incoming beer. The water is circulated through the coiled tube of the preheater. The remaining $20 \%$ of the bottoms is directed to the shell side of the boiler where it is vaporized and returned to the distillation column. The heat for boiling this flow is provided by geothermal fluid circulating through the tubes of the boiler.

This feed flow will be by manual control, as will product take-off. 


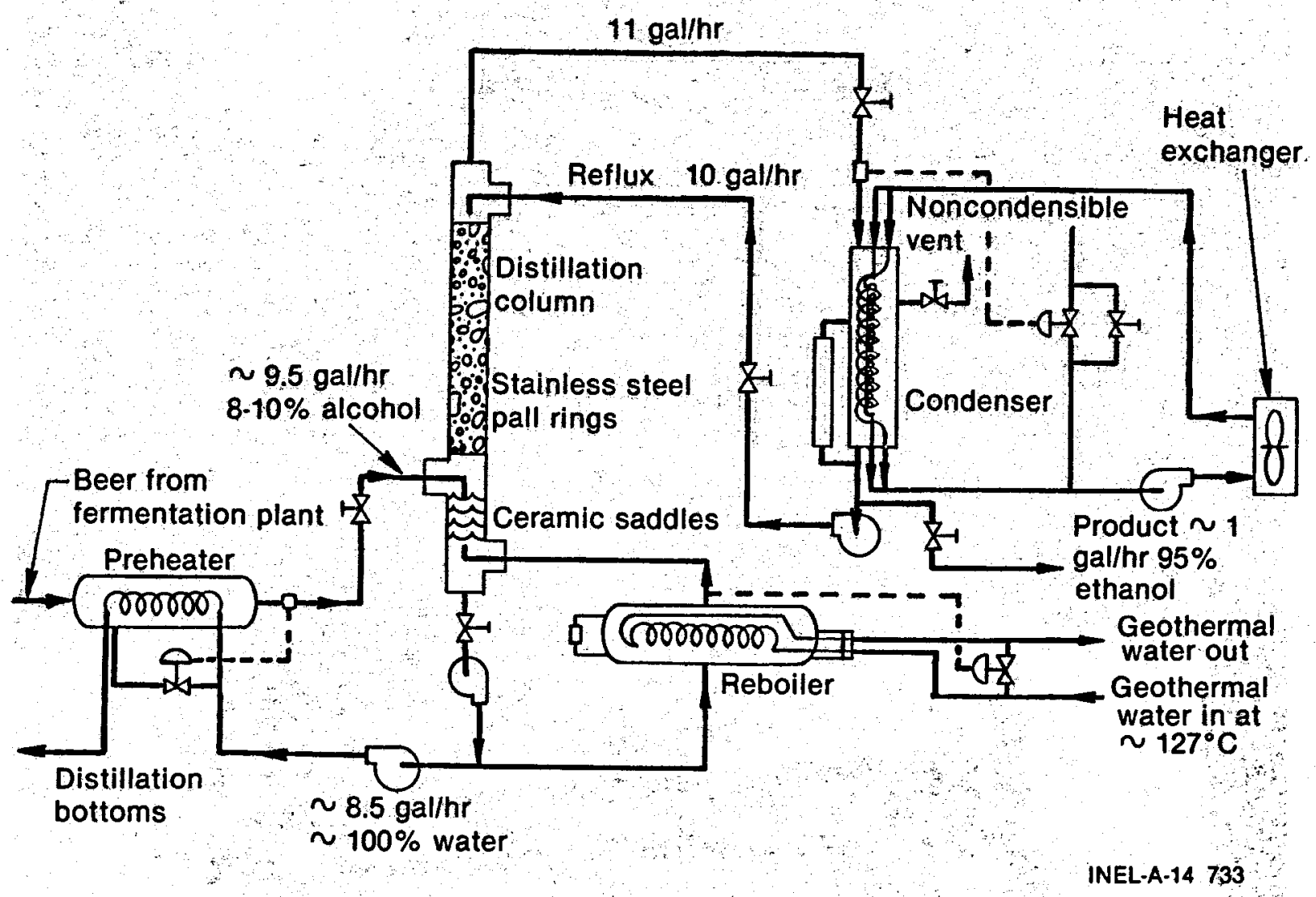

Figure 19. Flow diagram and equipment layout of the first phase of alcohol production (to $90 \%$ pure).

The operating pressure of the distillation column is essentially atmospheric or zero gauge pressure. This pressure is maintained by setting the speeds on the feed, reflux, and boiler pumps.

The distillate or cooled alcohol that is produced in the distillation column and not recycled as reflux is taken off the reflux pump discharge. This flows into a $0.02-\mathrm{m}^{3}$ safety can at a rate of 0.23 to $0.34 \mathrm{~m}^{3} / \mathrm{hr}$.

\section{Conclusions}

The small-scale geothermal demonstration plant was successful (shown in operation in Figure 20). Geothermal water temperatures as low as $112.8^{\circ} \mathrm{C}$ were used successfully to distill the alcohol to approximately $95 \%$. Analysis of mass flow rates and data collection is being continued. The second phase, to produce $99.9 \%$ alcohol is in the planning stages. 


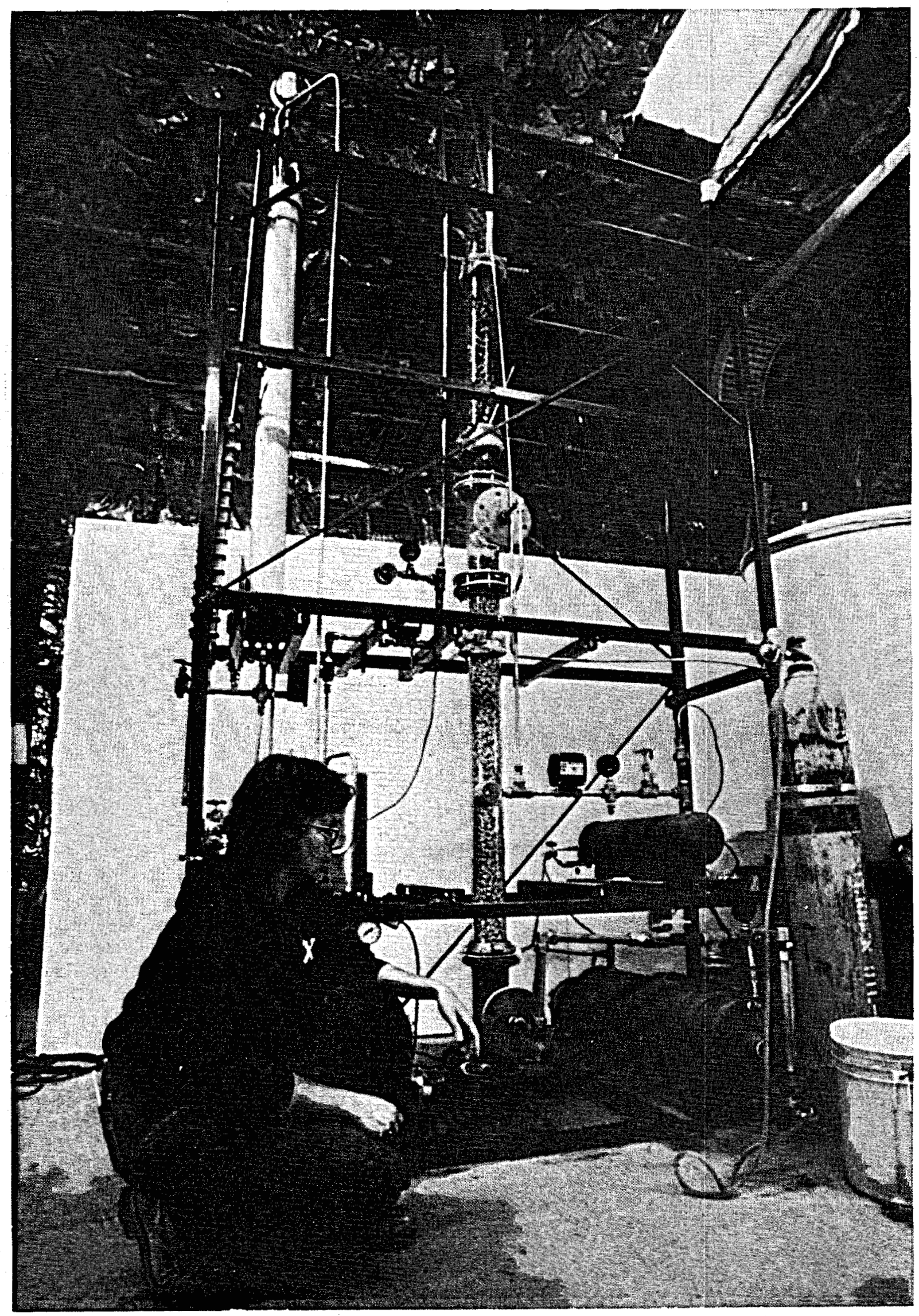

Figure 20. Small-scale geothermal demonstration plant. 


\section{BIBLIOGRAPHY}

See the following references for further information on applications of fluidized beds.

1. C. A. Allen, R. E. McAtee, E. S. Grimmett, "Liquid Fluidized-Bed Heat Exchanger Scale Control and Corrosion Tests," Thirteenth Intersociety Energy Conversion Engineering Conferences, August 20-25 1978.

2. C. A. Allen and E. S. Grimmett, "Liquid Fluidized Bed Heat Exchanger Design Parameters," ICP-1153, April 1978.

3. C. A. Allen, T. W. Lawford, D. H. Van Haaften, "Liquid Fluidized Bed Heat Exchanger for a 50 MW Plant," Geothermal Resource Council Transactions, 2, July 1978.

4. L. T. Cole and C. A. Allen, "Liquid Fluidized Bed Heat Exchanger Flow Distribution Models," ICP-1151, January 1979. 